\title{
MicroRNA as a Novel Modulator in Head and Neck Squamous Carcinoma
}

\section{Li-Hsin Chen, ${ }^{1,2}$ Kun-Ling Tsai, ${ }^{2,3}$ Yi-Wei Chen, ${ }^{3}$ Cheng-Chia Yu, ${ }^{4}$ Kuo-Wei Chang, ${ }^{5,6}$ Shi-Hwa Chiou, ${ }^{1,2,3}$ Hung-Hai Ku, ${ }^{7}$ Pen-Yuan Chu, ${ }^{8,9}$ Ling-Ming Tseng, ${ }^{10}$ Pin-I Huang, ${ }^{3,11}$ and Wen-Liang Lo ${ }^{5,6}$}

\author{
${ }^{1}$ Institute of Pharmacology, National Yang-Ming University, Taipei 11221, Taiwan \\ ${ }^{2}$ Department of Medical Research and Education, Taipei Veterans General Hospital, Taipei 11217, Taiwan \\ ${ }^{3}$ Institute of Clinical Medicine, School of Medicine, National Yang-Ming University, Taipei 11221, Taiwan \\ ${ }^{4}$ Institute of Oral Biology and Biomaterial Science, Chung Shan Medical University, Taichung 40201, Taiwan \\ ${ }^{5}$ Department of Dentistry, School of Dentistry, National Yang-Ming University, Taipei 11221, Taiwan \\ ${ }^{6}$ Division of Oral and Maxillofacial Surgery, Department of Stomatology, Taipei Veterans General Hospital, Taipei 11217, Taiwan \\ ${ }^{7}$ Institute of Anatomy and Cell Biology, National Yang-Ming University, Taipei 11221, Taiwan \\ ${ }^{8}$ School of Medicine, National Yang-Ming University, Taipei 11221, Taiwan \\ ${ }^{9}$ Otolaryngology \& Head and Neck Surgery, Department of Otolaryngology, Taipei Veterans General Hospital, Taipei 11217, Taiwan \\ ${ }^{10}$ Department of Surgery, Taipei Veterans General Hospital, Taipei 11217, Taiwan \\ ${ }^{11}$ Cancer Center, Taipei Veterans General Hospital, Taipei 11217, Taiwan
}

Correspondence should be addressed to Pin-I Huang, pihuang@vghtpe.gov.tw and Wen-Liang Lo, wllo@vghtpe.gov.tw

Received 18 October 2010; Accepted 30 December 2010

Academic Editor: Paul Magnus Schneider

Copyright (๑) $2010 \mathrm{Li}-\mathrm{H} \sin$ Chen et al. This is an open access article distributed under the Creative Commons Attribution License, which permits unrestricted use, distribution, and reproduction in any medium, provided the original work is properly cited.

MicroRNAs have emerged as important regulators of cell proliferation, development, cancer formation, stress responses, cell death, and other physiological conditions in the past decade. On the other hand, head and neck cancer is one of the top ten most common cancers worldwide. Recent advances in microRNAs have revealed their prominent role in regulating gene expression and provided new aspects of applications in diagnosis, prognosis, and therapeutic strategies in head and neck squamous carcinoma. In the present paper, we focus on microRNAs showing significant differences between normal and tumor cells or between cells with differential ability of metastasis. We also emphasize specific microRNAs that could modulate tumor cell properties, such as apoptosis, metastasis, and proliferation. These microRNAs possess the potential to be applied on clinical therapy in the future.

\section{Introduction}

Head and neck squamous cell carcinomas (HNSCCs) account for approximately 10,000 emerging patients in the USA per year. In the past 5 years, new subjects for HNSCC in the USA increased approximately $25 \%$, while the total initiated cancer cases only increased about $5 \%$ during the same period [1-6]. In Taiwan, HNSCC has been one of the 10 leading causes of cancer deaths in the past decades. The mortality rate also increased significantly, from 4.25 per 100,000 in 1995 to 9.6 per 100000 in 2006, a 2.26-fold increase in one decade [7]. Several risk factors for HNSCC have been reported, such as oropharynx-related problems, betel quid chewing, cigarette, and alcohol abuse [7-11]. Betel quid chewing is widespread in Taiwan, especially among the indigenous people and blue-collar workers, with a total estimated two million habitual users ( $10 \%$ of population) [12]. Betel quid chewing has also been associated with cancer prognosis in a dose- and time-dependent fashion. In a study of 378 HNSCCC patients, the 5-year survival rate of betel quid chewers was significantly lower than that of nonchewers [13]. Areca nut extract (ANE) is highly cytotoxic and genotoxic to cultured human oral mucosal epithelial cells and fibroblasts. Exposure of human keratinocytes to 
ANE results in apoptosis, generation of reactive oxygen species, genetic damage, and micronuclei formation [14]. The same study has found that a 24-hour treatment with ANE induced mutations at the hypoxanthine phosphoribosyltransferase (HPRT) locus in human keratinocytes [14]. Increased intracellular levels of reactive oxygen species and 8-hydroxyguanosine in cells exposed to ANE have been also reported [14]. Arecoline has been shown to induce structural chromosomal aberration, sister chromatid exchange, and micronuclei formation in different cell types $[15,16]$. Moreover, it has been shown that arecoline induced a significant elevation of cyclin-dependent kinase inhibitor 1 (p21/waf1) and a decline of cell division control protein 2 (cdc2) and cyclin B1 in gingival keratinocytes [17]. Despite the recent development of molecular-targeted therapeutics and other updated treatment regimens, HNSCC remains difficult to manage. Most patients with advanced HNSCC die from locoregional progression, with local recurrence rate up to $40 \%$ even after multimodality treatment $[8,18$, 19], indicating that a better understanding of molecular pathogenesis for this disease is urgently needed.

Several molecular pathways are involved in the process of HNSCC carcinogenesis. For instance, high expression of cyclin A and cyclin D1 raises the carcinogenicity in oral cancers. Besides, p2 $7^{\mathrm{Kip} 1}$, an inhibitor of cyclin-dependent kinases, has been reported as a prediction marker for survival rate [20-22]. As a tumor suppressor, p53 function is suppressed when overexpresing murine double minute gene 2 (MDM2) in oral cancer cells [23]. Moreover, many apoptosis-related, adhesion molecular-related, and inflammation-related proteins, such as activating protein-1 (AP1), survivin, Ras and Ras-related C3 botulinum toxin substrate 1 (Rac-1), cyclooxygenase-2 (COX-2), epidermal growth factor receptor (EGFR), human epidermal growth factor receptor 2 (Her-2), signal transducer, and activator of transcription 1 (STAT-1) as well as caspase-1, play important roles in HNSCC carcinogenesis [24-28].

MicroRNAs (miRNAs), approximately 18-25 nucleotides in length, are a group of endogenous small and noncoding RNAs. Since its first discovery in 1993, the biological function and biogenesis of miRNAs became popular topics for biomedical researches. They are transcribed to form a primary miRNA via RNA polymerase II. Primary miRNA is processed into precursor miRNA (pre-miRNA) by Drosha and DRG 8 and is then exported from nucleus to cytoplasm through exportin 5 . The pre-miRNA is modified by Dicer and the matured miRNA forms. There are about 1000 different miRNAs which have been discovered and estimated in human genome [29]. MiRNAs play a critical role in the regulation of gene expression. As expected, miRNAs expression is highly correlated with human diseases, such as cancer and aging [30]. MiRNAs donot only act as oncogenes but also as tumor suppressors, which further implicates their role as therapeutic targets [31].

The aim of this paper is to highlight miRNA as a novel modulator in HNSCC. Considering the rising importance of miRNA and increasing cases of HNSCC, we hope this paper would shed some light on cancer therapy and provoke ideas for new research in order to find out more details about and mechanisms beneficial for therapeutics of HNSCC.

\section{MiRNA-Related Ageing and Cancers}

Epigenetics of ageing is an emerging field involving the mechanisms that affect gene expressions other than inherited DNA sequences regulating the tumorigenesis in multiple cancers. Factors such as DNA methylation, histone modification, chromatin remodeling, the polycomb protein groups, and noncoding RNAs can all contribute to the broad variety of phenotypes of ageing. The category of small noncoding regulatory RNAs includes miRNAs, small interfering RNAs (siRNAs), PIWI-interacting RNAs (piRNAs), small nucleolar RNAs (snoRNAs), and small nuclear RNAs (snRNAs). Among these, we focused on a group of microRNAs and their impact on facets of organismal aging as well as cellular senescence. Most miRNA-mediated regulation occurs at the posttranslational level, primarily through its near-perfect or partial complementary fit against the coding region or $3^{\prime}$ untranslated region (UTR) of target mRNA, leading to translational repression and/or degradation, therefore, the regulation of gene expression. In rare cases, they may also promote translation [32, 33].

The roles of miRNAs in cancers have been extensively investigated in the past few years. The relevance of miRNAs in cancer was suggested by the changes in expression patterns [34] and recurrent amplification as well as deletion of miRNA genes in cancers. Calin et al. were the first to report the signature of 13 microRNAs capable of distinguishing between indolent and aggressive chronic lymphocytic leukemia (CLL) [35]. Since then, several miRNAs have emerged as candidate component of oncogenes and tumorsuppressor networks. The miRNAs aberrant expressions in cancers are summarized in Table 1.

It has been demonstrated that miRNAs can function both as oncogenes and tumor suppressors in the development of cancers. Recently, the connection of miRNA biogenesis and tumor suppressor networks was elucidated. p53 is a well-known tumor suppressor regulating diverse physical responses to many cancer-related stress signals, which could be translated to affect cell proliferation, cell death, DNA repair, and angiogenesis. Efforts have unraveled the linkage between $\mathrm{p} 53$ and several miRNAs. Xi et al. found that miR30a-5p, miR-181b, miR-372, let-7g, miR-26a, let-7b, miR296, and miR30a-3p were upregulated by wt-p53, whereas miR-15b, miR-27a, miR200c, miR-191, miR-30c, miR-25, miR-107, miR-339, miR-125, miR-27b, miR-23a, and miR10 a were downregulated by wt-p53 in human colon carcinoma cell lines [36], suggesting that $\mathrm{p} 53$ plays a role in a wide range of miRNA expression. Another study analyzing 470 miRNAs found that 12 miRNAs were significantly affected by $p 53$ [37]. Recent evidences indicated that miRNAs are directly regulated by $\mathrm{p} 53$. He et al. reported that miR$34 \mathrm{a}, \mathrm{miR}-34 \mathrm{~b}$, and miR-34c reflected p53 status and the expression of these miRNAs was induced by DNA damage and oncogenic stress in a p53-dependent manner leading to apoptosis or cellular senescence [38]. These findings 
TABLE 1: MicroRNA aberrant expression in cancer.

\begin{tabular}{|c|c|c|c|}
\hline Tumor type & Upregulated miRNA & Downregulated miRNA & References \\
\hline \multirow{3}{*}{ Glioblastoma } & miR-21 & & \multirow{3}{*}[121-125]{} \\
\hline & $\operatorname{miR}-221$ & $\operatorname{miR}-7$ & \\
\hline & $\operatorname{miR}-222$ & & \\
\hline \multirow{5}{*}{ Lung } & let7-5a & miR-1, let-7 family, miR-7, & \multirow{5}{*}[121,126-130]{} \\
\hline & miR-17-92 cluster, miR-18b, & miR-15a/miR-16, miR-29 & \\
\hline & miR-20a, miR-21, miR-34c, & family, miR-32, miR-137, & \\
\hline & miR-106a, miR-155, miR-182, & miR-342 & \\
\hline & $\operatorname{miR}-328$ & miR-145 & \\
\hline \multirow{6}{*}{ Breast } & miR-10b, miR-21, miR-22, & let-7, miR-7, miR-9-1, & \multirow{6}{*}[34,131-133]{} \\
\hline & miR-27a, miR-155, miR-210, & miR-17/miR-20, miR-31, & \\
\hline & miR-221, miR-222, miR-328, & miR-125a, miR-125b, & \\
\hline & & miR-146, miR-200 family, & \\
\hline & miR-373, miR-520c & miR-205, miR-206, & \\
\hline & & miR-335 & \\
\hline \multirow{3}{*}{ Hepatocellular carcinoma } & miR-17-92 cluster, miR-21, & miR-1, miR-34a & \multirow{3}{*}[134-140]{} \\
\hline & miR-143, miR-221 & miR-101, miR-122a & \\
\hline & miR-224 & $\operatorname{miR}-125 b$ & \\
\hline Gastric cancer & miR-21, miR-27a, miR-130b & miR-101, miR-143, miR-145 & {$[141-143]$} \\
\hline \multirow[t]{2}{*}{ Colorectal cancer } & \multirow[t]{2}{*}{ miR-17-92 cluster, miR-21 } & $\begin{array}{l}\mathrm{miR}-34 \mathrm{a}, \mathrm{miR}-34 \mathrm{~b} / \mathrm{c} \\
\mathrm{miR}-127, \mathrm{miR}-143\end{array}$ & \multirow[t]{2}{*}[144-149]{} \\
\hline & & miR-145, miR-342 & \\
\hline \multirow{3}{*}{ Prostate cancer } & \multirow{3}{*}{ miR-221, miR-222 } & miR-15a-miR-16-1 cluster, & \multirow{3}{*}[144,150-153]{} \\
\hline & & miR-101, miR-127, & \\
\hline & & $\operatorname{miR}-449 \mathrm{a}$ & \\
\hline Lymphoma & miR-17-92 cluster, miR-155 & miR-143, miR-145 & {$[154-156]$} \\
\hline \multirow{3}{*}{ CLL } & \multirow{3}{*}{ miR-21, miR-155 } & miR-15, miR-16, miR-29b, & \multirow{3}{*}[35,156-160]{} \\
\hline & & miR-29c, miR-34a, & \\
\hline & & $\begin{array}{l}\text { miR-143, miR-145, miR-181b, } \\
\text { miR-223 }\end{array}$ & \\
\hline
\end{tabular}

CLL: chronic lymphocytic lymphoma.

elucidated that miRNAs play crucial roles in the p53 tumor suppressor pathways.

\section{MiRNAs Target Molecular Pathways in HNSCC}

3.1. MiRNA Expression Profiles. MiRNA profiling in head and neck cancer has been reviewed by Liu et al. and Tran et al. [39, 40]. Recently reported HNSCC-related miRNAs expression profiling is summarized in Table 2. Some miRNAs show consistently altered expressions in different studies. For example, the upregulated expression of miR21, miR-31, miR-18, and miR-221 has been reported in at least 2 different study series. Similarly, the expression of miR-133a, miR-133b, miR-125a, miR-138, miR-139, miR200c, miR-26b, miR-302b, miR-302c, miR-342, miR-371, and miR-373, is consistently reported to be downregulated in HNSCC. Exception for certain miRNAs, all published miRNA profiling shared little in common. This may be due to various types of sample applied. Generally, the analysis of upregulation and downregulation of miRNA profiles were of consistence. However, there still were considerable variations between different researches. These discrepancies may be due to different sampling locations/cell lines (miR-9, 16, 23b, 29c, 31, 34b, 138, 221, 375, and 449), methods for performing the assays (miR-16, 29c, and 340), and scope of the microarrays (miR-16, 23b, 29c, 221, 340, 375, and 449). For example, the same miRNAs possessed opposite profiles between the squamous cell carcinomas and the nasopharyngeal carcinomas/pleomorphic adenomas. These manifestations might be contributed from different cell differentiations that were modulated by the same miRNAs under various circumstances. Sampling technique of the tumor tissue also influenced the proportion of tumor cells to nontumor cells that may interfere with the sensitivity of real-time PCR and microarray analysis.

3.2. MiRNAs Affect Apoptosis or Metastasis. There are several reasons indicating that miRNAs play several roles in human cancer, one of which is miRNAs-mediated cell death. 
TABLE 2: Antecedent studies identified microRNA expression level change in head and neck cancer.

\begin{tabular}{|c|c|c|c|c|}
\hline miRNA & Up-regulated & Down-regulated & Study groups/methods & References \\
\hline $\begin{array}{l}\text { let7i;15a; 15b; 17a; 18; 18a; 18b; } \\
\text { pre 21; 21; 21-17p; 24-1p; 98; } \\
\text { 99b; 104; 126; 130b; 137; 140; } \\
\text { 142-3p; 146; 146b; 151; 152; 155; } \\
\text { 181b; 181d; 184; 188; 192; 193b; } \\
\text { 199b-2p; pre-205; 213; 301; 325; } \\
\text { 333; 337; 338; 374; 455; 491 }\end{array}$ & 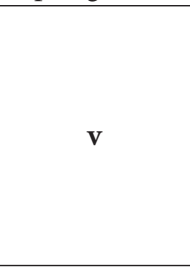 & & & $\begin{array}{l}{[61,102,113} \\
115,161-167]\end{array}$ \\
\hline $\begin{array}{l}\text { let-a family; let-7 family; let7a; } \\
\text { 10b; 20b; } 23 \text { family; } 27 \text { family; } \\
\text { 30; } 34 \text { family; 34c; 93-7p; 99a; } \\
\text { 100; 107; 125; 125a; 127; 144; } \\
\text { 154; 195; 200 family; 200a; } \\
\text { 291-3p; 368; 370; 378; 422 } \\
\text { family; 494 }\end{array}$ & & $\mathbf{v}$ & & $\begin{array}{c}{[61,102,113} \\
114,119,162 \\
164-168]\end{array}$ \\
\hline \multirow{2}{*}{9} & \multirow[t]{2}{*}{$\mathbf{v}$} & & $13 \mathrm{NPC} /$ real time-PCR & {$[162]$} \\
\hline & & $\mathbf{v}$ & $\begin{array}{l}18 \text { OC cell } \\
\text { lines/real-time-PCR }\end{array}$ & {$[164]$} \\
\hline \multirow[t]{2}{*}{16} & \multirow[t]{2}{*}{$\mathbf{v}$} & & $\begin{array}{l}9 \text { HNSCC cell } \\
\text { lines/Microarray }\end{array}$ & {$[113]$} \\
\hline & & $\mathbf{v}$ & $31 \mathrm{NPC} /$ real time-PCR & {$[166]$} \\
\hline \multirow{2}{*}{17} & \multirow[t]{2}{*}{$\mathbf{v}$} & & $13 \mathrm{NPC} /$ real time-PCR & {$[162]$} \\
\hline & & $\mathbf{v}$ & $31 \mathrm{NPC} /$ real time-PCR & {$[166]$} \\
\hline \multirow[t]{2}{*}{$23 b$} & \multirow[t]{2}{*}{$\mathbf{v}$} & & $\begin{array}{l}104 \mathrm{HNSCC} / \text { Microarray and } \\
\text { real time-PCR }\end{array}$ & {$[102]$} \\
\hline & & $\mathbf{v}$ & 5 SCC/real time-PCR & {$[165]$} \\
\hline \multirow{2}{*}{$29 \mathrm{c}$} & \multirow[t]{2}{*}{$\mathbf{v}$} & & 4 HNSCC/Microarray & {$[114]$} \\
\hline & & $\mathbf{v}$ & $31 \mathrm{NPC} /$ real time-PCR & {$[166]$} \\
\hline \multirow{2}{*}{31} & \multirow[t]{2}{*}{$\mathbf{v}$} & & 18 OC cell lines/real time-PCR & {$[164]$} \\
\hline & & $\mathbf{v}$ & $13 \mathrm{NPC} /$ real time-PCR & {$[162]$} \\
\hline \multirow[b]{2}{*}{$34 \mathrm{~b}$} & $\mathbf{v}$ & & 5 SCC/real time-PCR & {$[165]$} \\
\hline & $\mathbf{v}$ & $\begin{array}{l}13 \mathrm{NPC} / \mathrm{real} \\
\text { time-PCR } \\
31 \mathrm{NPC} / \mathrm{real} \\
\text { time-PCR }\end{array}$ & {$[162,166]$} & \\
\hline \multirow{2}{*}{138} & \multirow[t]{2}{*}{$\mathbf{v}$} & & $13 \mathrm{NPC} /$ real time-PCR & {$[162]$} \\
\hline & & $\mathbf{v}$ & 4 OSCC/real time-PCR & {$[61]$} \\
\hline \multirow[t]{2}{*}{221} & \multirow[t]{2}{*}{$\mathbf{v}$} & $\begin{array}{c}99 \mathrm{HNSCC} \text { and } 14 \\
\text { normal/Microarray } \\
\text { and real time-PCR } \\
5 \text { SCC/real time-PCR }\end{array}$ & {$[115,165]$} & \\
\hline & & $\mathbf{v}$ & $31 \mathrm{NPC} /$ real time-PCR & {$[166]$} \\
\hline \multirow{2}{*}{340} & \multirow[t]{2}{*}{$\mathbf{v}$} & & $18 \mathrm{OC}$ cell lines/real time-PCR & {$[164]$} \\
\hline & & $\mathbf{v}$ & $\begin{array}{l}9 \text { HNSCC cell } \\
\text { lines/Microarray }\end{array}$ & {$[113]$} \\
\hline \multirow{3}{*}{375} & $\mathbf{v}$ & & $169 \mathrm{HNSCC} /$ real time-PCR & {$[161]$} \\
\hline & \multirow[t]{2}{*}{$\mathbf{v}$} & $\begin{array}{l}99 \text { HNSCC and } 14 \\
\text { normal/Microarray } \\
\text { and real time-PCR }\end{array}$ & {$[115,167]$} & \\
\hline & & $\begin{array}{l}16 \text { pleomorphic } \\
\text { adenoma/Microarray } \\
\text { and real time-PCR }\end{array}$ & & \\
\hline \multirow[t]{2}{*}{449} & \multirow[t]{2}{*}{$\mathbf{v}$} & & $\begin{array}{l}16 \text { pleomorphic } \\
\text { adenoma/Microarray and real } \\
\text { time-PCR }\end{array}$ & {$[167]$} \\
\hline & & $\mathbf{v}$ & $\begin{array}{l}9 \text { HNSCC cell } \\
\text { lines/Microarray }\end{array}$ & {$[113]$} \\
\hline
\end{tabular}


Apoptosis is the active process of programmed cell death. It happens in multicellular organisms and is controlled by an intracellular program of gene expression. In humans, the balance between proliferation and apoptosis is important and essential for homeostasis maintenance. Tumorigenicity would be relatively easy to take place when this homeostasis collapses. MiRNAs mediate tumorigenicity by directly targeting antiapoptotic genes expression or proapoptosis genes expression.

Metastasis, on the other hand, is another specific property of cancer cells. MiRNAs directly influence metastasis and have great impact on prognosis in clinical evaluation. Many studies to be discussed below in this paper showed that miRNAs inhibition or overexpression affected both apoptosis and metastasis. However, it is difficult to tell if the results of migration or invasion were impacted by their effects on apoptosis despite that some miRNAs have been proved to directly target genes involved in metastatic capability. Table 3 lists all miRNAs discussed below.

3.2.1. Potential Tumor Suppressors. Several miRNAs are found to act as tumor suppressors. Hong et al. reported that inhibition of miR-296 expression could promote esophageal squamous cell carcinoma apoptosis. MiR-296 could upregulate $\mathrm{Bcl}-2$-associated $\mathrm{X}$ protein (Bax) expression, downregulate $\mathrm{B}$-cell lymphoma 1 protein $(\mathrm{Bcl})$ expression, suppress cyclin D1 and p27 expression, and promote the chemotherapeutic sensitivity [41]. Long et al. showed that up-regulation of let-7a promotes laryngeal cancer cell dysfunction by modulating proliferation, inhibiting metastasis, and inducing apoptosis [42]. Comparing to normal human laryngeal cells or nondifferentiated cells, let-7a miRNA expression level was highly suppressed. Furthermore, in the same study, let-7a affected RAS and c-Myc expression in protein level, thus mediated cell apoptotic genes and oncogenes expression. Reduction of miR-138, on the other hand, was found in highly metastatic cells. Enforced expression of miR-138 could mitigate invasion, lead to cell cycle arrest, and induce cell apoptosis [43]. However, it is hard to tell if miR-138 does affect the ability of invasion or it is simply impacted by raising the percentage of apoptosis. Recently, the same group further demonstrated the role of miR138 in metastasis. They showed that miR-138 modulated migration and invasion through targeting Ras homolog gene family, member C (RhoC) and Rho-associated, coiled-coil containing protein kinase 2 (ROCK2). Inhibition of miR-138 caused elongated cell morphology, increased cell stress fiber generation, and enhanced cell migration as well as invasion [44]. Other miRNAs such as miR-204 and miR-34c also inhibit invasion. Lee et al. had shown that miR-204 is a newly targeting gene which is a suppressor of metastasis in head and neck cancer. Enhancement of miR-204 expression directly led to the reduction of proliferation, invasion, and migration in HNSCC cell lines and mitigated experimental lung organ metastasis in animal study [45]. They also demonstrated that overexpression of miR-204 is associated with early recurrence in those HNSCCs expressing EGFR-pathway signature. MiR$34 \mathrm{c}$, on the contrary, functioned as tumor suppressor that targeted 3'UTR of c-Met and inhibited cell growth and invasion [46]. This suggested that downregulation of miR$34 \mathrm{c}$ may contribute to malignancy in human laryngeal carcinoma through a mechanism involving targeting of cMet.

3.2.2. Apoptotic Antagonists or Metastasis Stimulators. On the contrary, several miRNAs act as a mediator of apoptotic antagonist or promote metastasis. Zhang et al. demonstrated that miR-141 could influence cell cycle, apoptotic phenotype, cell migration and invasion by regulating Bromodomaincontaining protein 3 (BRD3), Ubiquitin-associated protein 1 (UBAP1), c-Jun $\mathrm{N}$-terminal kinases (JNK), serine/threonine protein kinase (Akt/PKB), and phosphatase and tensin homolog (PTEN) signaling transduction pathways in nasopharyngeal carcinoma. The study showed a highly positive correlation between miR-141 and c-Myc expression and an opposite expression pattern between miR141 and short palate, lung, and nasal epithelium clone 1 (SPLUNC1) [47]. Lee et al. published that miR-373 plays a pivotal role in regulating large tumor suppressor that homolog 2 (LATS2), a tumor suppressor has been implicated in modulating cell cycle and inducing apoptosis [48, 49]. MiR-373 is therefore considered to be a proliferation stimulator and an apoptosis inhibitor in human esophageal cancer [50]. MiR-21-attenuated cancer cells provoke apoptosis via modulating anti-apoptotic proteins. MiR-21 is found to target programmed cell death 4 gene (PDCD4), tropomyosin 1 (TPM1), and PTEN to inhibit apoptosis, promote transformation, and enhance colony formation [7, 51-53]. MiR21 inhibitor displayed a statistically significant enhance in cytochrome c release and apoptotic expression, indicating that mir-21 is an unequivocal oncogenic miRNA in HNSCC. Recently, we explored that CD44, aldehyde dehydrogenase 1 (ALDH1), and phosphorylated STAT3 (p-STAT3) were higher in high-grade HNSCCs and that triple positivity for CD44/ALDH1/p-STAT3 indicated a worse prognosis for HNSCC patients [54]. In this study, CD $44^{+} \mathrm{ALDH} 1^{+}$ cells isolated from seven HNSCC patients showed greater tumorigenicity, radioresistance, and high expression of stemness (Bmi-1/Oct-4/Nanog) and epithelial-mesenchymal transitional (Snail/Twist) genes as p-STAT3 level increased. Recent studies showed that mir-21 is a key determinant in IL-11/STAT3 anti-apoptotic signaling pathway [55] and STAT3 activation of miR-21 and miR-181b-1 via PTEN and cylindromatosis (CYLD) are part of the epigenetic switch linking inflammation to cancer [56].

Additionally, a correlation was found between miR-211 expression level and the cancer metastasis in human oral carcinoma. MiR-211 expression is higher in tumors with vascular invasion and is correlated with poor prognosis. Enforced miR-211 expression intensively increased migration, colony formation, and tumorigenicity in oral squamous cell carcinoma (OSCC) cell line [57]. miR-222, on the other hand, regulates metalloproteinase 1 (MMP1) and manganese superoxide dismutase 2 (SOD2) expression by targeting their $3^{\prime}$ UTR [58]. The reasons of miR-222 inhibited invasion was through both cis- and trans-regulatory mechanisms [58]. 
TABLE 3: miRNAs involved in tumorigenesis of HNSCC.

\begin{tabular}{|c|c|c|c|c|}
\hline microRNA & Tumor sites or cell lines & Physiological effects & Potential target(s) & Reference(s) \\
\hline let-7a & $\begin{array}{l}\text { Laryngeal squamous cancer tissues; } \\
\text { Hep-2 cells }\end{array}$ & $\begin{array}{l}\text { Let-7a mimic transfection suppressed } \\
\text { proliferation and induced apoptosis in } \\
\text { Hep-2 cells }\end{array}$ & RAS and c-MYC & {$[42]$} \\
\hline miR-10b & $\begin{array}{l}\text { Human esophageal cancer cell lines } \\
\text { (KYSE30, KYSE70, KYSE140, } \\
\text { KYSE150, KYSE410, KYSE450, } \\
\text { KYSE510, and EC9706) }\end{array}$ & $\begin{array}{l}\text { Ectopic expression of miR-10b } \\
\text { promoted migration and invasion }\end{array}$ & KLF4 & [169] \\
\hline miR-15a & HNSCC SQ20B cell line & $\begin{array}{l}\text { miR-15a inhibition promoted DNA } \\
\text { synthesis }\end{array}$ & Cyclin E & {$[60]$} \\
\hline miR-21 & $\begin{array}{l}\text { Primary tongue carcinoma and } \\
\text { primary esophageal squamous cell } \\
\text { carcinomas; human tongue cancer cell } \\
\text { lines (SCC-15 and CAL27) and } \\
\text { esophageal squamous cell carcinoma } \\
\text { cell lines (TE6, TE8, TE10, TE11, } \\
\text { TE12, and TE14) }\end{array}$ & $\begin{array}{l}\text { miR- } 21 \text { inhibition inhibited cell } \\
\text { growth and promoted apoptosis }\end{array}$ & $\begin{array}{l}\text { TPM1, PTEN, and } \\
\text { PDCD } 4\end{array}$ & {$[51-53]$} \\
\hline miR-31 & OSCC SAS cell line & $\begin{array}{l}\text { Ectopic expression increased the } \\
\text { oncogenic potential of HNSCC cells } \\
\text { under normoxia conditions }\end{array}$ & FIH & {$[73]$} \\
\hline miR-100 & UPCI:SCC029 cells & $\begin{array}{l}\text { Transfection of miR-100 mimics } \\
\text { inhibited proliferation }\end{array}$ & $\begin{array}{l}\text { D1, EGR2, } \\
\text { MMP13, and } \\
\text { FGFR3 }\end{array}$ & {$[62]$} \\
\hline miR-125b & UPCI:SCC029 cells & $\begin{array}{l}\text { Transfection of miR-125b mimics } \\
\text { inhibited proliferation }\end{array}$ & $\begin{array}{l}\text { KLF13, CXCL11, } \\
\text { and FOXA1 }\end{array}$ & {$[62]$} \\
\hline miR-138 & $\begin{array}{l}\text { Six paired HNSCC cell lines } \\
\text { (UM1/UM2, 1386 Tu/1386Ln and } \\
\text { 686Tu/686Ln with different migration } \\
\text { or invasion ability }\end{array}$ & $\begin{array}{l}\text { Ectopic expression caused cell cycle } \\
\text { arrest, apoptosis, and suppressed } \\
\text { invasion }\end{array}$ & RhoC and ROCK2 & {$[43,44]$} \\
\hline miR-141 & $\begin{array}{l}\text { 5-8F cell line (an NPC cell line) } \\
\text { knockdowned c-MYC or re-expressed } \\
\text { SPLUNC1 }\end{array}$ & $\begin{array}{l}\text { miR-141 inhibition decreased } \\
\text { migration, inhibited invasion, and } \\
\text { slightly enhanced apoptosis }\end{array}$ & $\begin{array}{l}\text { BRD3, UBAP1, } \\
\text { and PTEN }\end{array}$ & {$[47]$} \\
\hline miR-184 & $\begin{array}{l}\text { TSCC Cal27, HN21B, and HN96 cell } \\
\text { lines }\end{array}$ & $\begin{array}{l}\text { miR-184 inhibition resulted in } \\
\text { proliferation inhibition and apoptosis }\end{array}$ & c-Myc & {$[61]$} \\
\hline miR-196 & Esophageal cancer tissues & $\begin{array}{l}\text { Downregulation of miR-196 inhibited } \\
\text { growth and conferred drug-sensitivity } \\
\text { of esophageal cancer cells }\end{array}$ & N.D. & {$[41]$} \\
\hline miR-200c & 5 primary HNSCC CSC & $\begin{array}{l}\text { Upregulation of miR-200c inhibited } \\
\text { the cancer stem cell-like properties of } \\
\mathrm{ALDH} 1^{+} \mathrm{CD} 44^{+} \mathrm{HNSCC}\end{array}$ & Bmi-1 & To be published \\
\hline miR-203 & HNSCC JHU-012 cells & $\begin{array}{l}\text { miR-203 induced cell cycle arrest and } \\
\text { apoptosis upon UVC irradiation }\end{array}$ & DeltaNp63 & {$[64]$} \\
\hline miR-204 & $\begin{array}{l}\text { HNSCC cell lines (SCC25, SCC 35, } \\
\text { SCC58, SCC61, SCC135, SCC151, } \\
\text { SQ20B, SQ38, and JSQ3) }\end{array}$ & $\begin{array}{l}\text { miR-204 mimics repressed } \\
\text { proliferation, invasion, and migration }\end{array}$ & N.D. & {$[45]$} \\
\hline $\operatorname{miR}-210$ & $\begin{array}{l}\text { Pancreatic cancer cell line SU86.86 and } \\
\text { Fadu cells }\end{array}$ & $\begin{array}{l}\text { Ectopic expression repressed xenograft } \\
\text { tumor growth }\end{array}$ & $\begin{array}{l}\text { HOXA1, HOXA9, } \\
\text { and FGFRL1 }\end{array}$ & {$[70]$} \\
\hline miR-211 & OSCC SAS cell line & $\begin{array}{l}\text { Enforced expression of miR- } 211 \\
\text { enhanced migration, invasion, and } \\
\text { colony formation }\end{array}$ & N.D. & {$[57]$} \\
\hline miR-222 & HNSCC UM1/UM2 cell lines & $\begin{array}{l}\text { Transfection of miR-222 mimics } \\
\text { inhibited invasion }\end{array}$ & MMP1 and SOD2 & {$[58]$} \\
\hline miR-373 & $\begin{array}{l}\text { The esophageal cancer cell lines } \\
\text { (CE48T, CE146T, KYSE70, KYSE150, } \\
\text { KYSE170, KYSE5, 10KYSE50, and } \\
\text { CE81T) }\end{array}$ & $\begin{array}{l}\text { miR- } 373 \text { enhances cell proliferation in } \\
\text { esophageal cancer cell lines }\end{array}$ & LATS2 & {$[50]$} \\
\hline miR-503 & UMSCC10B cell line & $\begin{array}{l}\text { Transfection of miR- } 503 \text { decreased S } \\
\text { phase and cell growth }\end{array}$ & Cyclin D1 & {$[59]$} \\
\hline
\end{tabular}

N.D: not determined.

Abbreviations: HNSCC: head and neck squamous cell carcinoma; OSCC: oral squamous cell carcinoma. NPC: nasopharyngeal carcinoma; TSCC: tongue squamous cell carcinoma; CSC: cancer stem cell. 
3.3. Proliferation. The capability of proliferation is a vital element of cancer cells. MiRNAs could target and regulate genes involved in cell cycle control or proliferation stimulation, and therefore, play a key role in modulating the phenotypes of cancer cells. Despite the promotion of metastatic ability of miR-211, forced expression of miR-211 accompanied with enhanced proliferation [57]. However, the underlying mechanism is still unknown. On the other hand, cyclin D1 is frequently overexpressed in cancer cells. Jiang et al. focused on cyclin D1 and tried to identify specific miRNAs targeting its mRNA. They found that miR-503 could not only suppress luciferase activity in reporter assay but also reduce mRNA and the protein level of cyclin D1 in human HNSCC cell line, UMSCC10B [59]. Despite the fact that miR-503 could alter S-phase and cause inhibition of cell proliferation, the physiological significance of miR-503 in HNSCC is still lacking. Cyclin E, another cell cycle regulator, is regulated by miR-15a. Anti-miR-15a, therefore, promoted DNA synthesis [60]. MiR-184 was discovered by comparing 4 tongue carcinomas and paired normal tissues through TaqMan miRNA assays. MiR-184 inhibition leads to proliferation inhibition, c-Myc reduction, and apoptosis in three SCC cell lines [61]. However, the authors did not explain the reduction of c-Myc nor if apoptosis was direct or indirect consequence of miR-184 inhibition. Further examination is required to understand the downstream targets of miR184. Due to unknown mechanism, the plasma level of miR184 highly was correlated with tumor status and seems to be a potential biomarker for SCC. MiR-100 and miR$125 \mathrm{~b}$ are downregulated in OSCC. Exogenous expression of these two miRNAs could reduce cell proliferation [62]. However, the study only provided potential targets affected by miR-100 and miR-125b mimicking transfection. The direct targets are still undetermined. While Ubiquitin-like protein SUMO-1 conjugating enzyme (Ubc9) is upregulated in breast, head and neck, and lung cancer specimens, it could also be regulated by miR-30e [63]. In $\mathrm{HeLa}$ cells, ectopic expression of miR-30e could negatively regulate Ubc9 expression and suppress cell growth. Whether miR-30e has the same effects in HNSCC cells still needs to be verified. Additionally, in response to genotoxic stress, altered miRNAs might be associated with stress responses and be responsible for drug resistance of tumor cells. In HNSCC, for instance, miR-203 targets DeltaNp63 in response to genotoxic stress [64]. Under ultraviolet light c (UVC) exposure, miR-203 was upregulated and correlated with DeltaNp63 decrement. MiR-203, therefore, can regulate DeltaNp63 expression and control cell survival upon genotoxic stress.

\section{The Relationship between MiRNAs, Hypoxia, and Epithelial-Mesenchymal Transition and Cancer}

Poor prognosis of HNSCC patients was found to related to hypoxia [65-67] and epithelial-mesenchymal transition (EMT) [68]. Hypoxia is a critical and major feature of cancer microenvironment. It could affect and determine many vital responses of tumor cells and account for protection toward radiotherapy and chemotherapy. Yang and Wu. found that the hypoxic response is mainly mediated by hypoxia inducible factor-1 (HIF-1) that promotes EMT through direct regulation of a basic-helix-loop-helix transcription factor (TWIST) expression. They concluded that coexpression of HIF- $1 \alpha$, TWIST, and Snail could be used as a prognostic marker in HNSCC patients [69]. Several miRNAs, such as miR-210, are found to be hypoxia inducible. Upon hypoxia, miR-210 expression is induced. The majority of target candidates of miR-210 are genes expressed under normoxia. When miR-210-overexpressed cell lines were xenotransplanted into the mice, the tumor volumes were lower than the parental control. It suggests the fact that miR-210 may participate in tumor initiation in response to hypoxia [70] and is a prognostic indicator in HNSCC [71]. Two other miRNAs are also associated with hypoxia. MiR-31 ablates expression of HIF and regulates hypoxia responses $[72,73]$. Also, in hypoxia, the expression of miR98 is elevated, and it targets high-mobility group AT-hook 2 (HMGA2), which sensitizes HNSCC to topoisomerase II inhibitor, doxorubicin [74].

Epithelial-mesenchymal transition is a process by which epithelial cells lose their polarity and are converted to a mesenchymal phenotype, which has been recently regarded as the critical event to induce morphogenetic changes during embryonic development, organ fibrosis, and tumor metastasis [75-78]. Phenotypic changes of EMT include the downregulation of epithelial markers (e.g., E-cadherin, desmoplakin and plakoglobin) and upregulation of mesenchymal markers (e.g., vimentin, fibronectin, and $\alpha$-smooth muscle actin) [75-78]. Transcriptional factors including Snail, Slug, TWIST, Zeb1, Zeb2, and E47 were shown to induce EMT through the repression of E-cadherin, and they are perceived as EMT regulators [79-84]. Major causes of HNSCC-related deaths are cervical node and distant metastasis. EMT was demonstrated to be the major mechanism responsible for mediating invasiveness and metastasis of late-stage cancers. Dr. Yang and his colleagues explored that Nibrin (NBS1) overexpression upregulated the expression of an EMT regulator Snail and its downstream target matrix metalloproteinase-2 [85]. Recent evidence suggests that depletion of the population of cancer stem cells (CSCs) decreases cancer recurrence and metastasis [86]. Prince et al. further demonstrated that the purified $\mathrm{CD} 44^{+}$population of HNSCC cells possesses the properties of cancer stem cells [87]. Subpopulation of CD44 positive cells showed chemoresistant genes ATP-binding cassette subfamily B member 1 (ABCB1), ATP-binding cassette sub-family G member 2 (ABCG2), cytochrome $\mathrm{P}_{450} 2 \mathrm{C} 8$ (CYP2C8), and telomerase reverse transcriptase (TERT) [88]. Our previous work showed that $\mathrm{ALDH}^{+}$-lineage plays a crucial role in maintaining self-renewal and cancer stem-like properties in HNSCC cells [89]. ALDH1 ${ }^{+}$-lineage cells are shown to have EMT shifting and endogenously co-expressed snail. Furthermore, the knockdown of snail expression significantly decreased the expression of ALDH1, inhibited cancer stem-like properties, and blocked the tumorigenic abilities of $\mathrm{CD} 44^{+} \mathrm{CD} 24^{-} \mathrm{ALDH} 1^{+}$cells [89]. We also explored the enriched OC-SLC which possesses the characteristics of both 
TABLe 4: Potential miRNAs for prognosis in HNSCC.

\begin{tabular}{lccc}
\hline Potential microRNA as prognostic marker & Type of abnormal expression & Type of samples & Reference(s) \\
\hline $\begin{array}{l}\text { miR-21 } \\
\text { miR-181b }\end{array}$ & Overexpression & OSCC & {$[116]$} \\
miR-345 & Underexpression & & \\
Combined Let-7d and miR-205 & Overexpression & HNSCC & {$[102]$} \\
miR-21 & Overexpression & TSCC & {$[51]$} \\
miR-210 & Overexpression & OSCC & {$[71]$} \\
miR-211 & Overexpression & ESCC & {$[57]$} \\
miR-296 & Overexpression of miR-221 & HNSCC & {$[41]$} \\
Combined miR-221 and miR-375 & Underexpression of miR-375 & & {$[115]$} \\
\hline
\end{tabular}

OSCC: oral squamous carcinoma cell; HNSCC: head and neck squamous carcinoma cells; TSCC: tongue squamous carcinoma cell; ESCC: esophageal squamous carcinoma cells.

stem cells and malignant tumors [90]. Additionally, expression of stemness markers (Nanog/Oct-4/CD133) contradicts the survival prognosis of OSCC patients [90]. Our data showed that $\mathrm{ALDH} 1^{+}$cells from HNSCC displayed higher levels of Bmi-1, and we further found that Bmi-1-silenced $\mathrm{ALDH}^{+}$cells showed increased sensitivity to radiotherapy and lower abilities for tumor invasion, colony formation, and self-renewal. Survival analysis further demonstrated that the mean survival rate of mice with $\mathrm{ALDH} 1^{+}$tumors under radiation treatment was significantly improved by knockdown of Bmi-1 [91]. More recently, Song et al. showed that Bmi-1 could directly promote EMT and malignancy in nasopharyngeal carcinoma by regulating snail [92]. Furthermore, there is growing evidence of the crosstalk and correlation between stemness pathways, tumor progression, and metastasis. The functional and mechanical significance of the overexpressed biomolecular pathway in HNSCC-CSC, however, is still blurred and needs to be clarified.

Several miRNAs were reported to be associated with CSC in hepatocellular carcinoma, pancreatic cancer, breast cancer, and brain tumors [93-96]. It has been reported that overexpression of miR34 impairs the self-renewal properties of CSC isolated from brain tumors and pancreatic cancer $[94,97]$. Tumorigenicity of breast CSC is also suppressed by ectopic let-7, miR200c, and miR30 expression [98-100]. MiR-181 family members are highly expressed in liver CSC, and silencing of miR-181 may eradicate liver cancer [93]. Therefore, it is of interest to ask whether microRNA is involved in regulating self-renewal and metastatic properties in HNSCC or HNSCC-associated CSC. In HNSCC, multiple miRNAs have been reported to be involved in HNSCC pathogenesis. It has been found that expression of oncogenic miR21 and miR184 promotes tumorigenicity in HNSCC $[51,61]$. In contrast, ectopic expression of tumor-suppressive miR98, miR-137, and miR-193a resulted in a loss of cell growth of HNSCC. Recent clinicopathological findings demonstrated that the down-regulation of miR-133a, miR133b, miR-205, and let-7d in HNSCC tumor tissues could be utilized for predicting the prognosis of patients with HNSCC $[101,102]$. Our previous study also demonstrated that oncogenic miR31 and miR221 upregulated HIF expression and elevated tumorigenicity in HNSCC $[57,73]$.

MicroRNAs can act not only as oncogenes but also as tumour suppressors $[29,30]$. Therefore, it is plausible to consider miRNAs as therapeutic targets in cancer cells [31]. $\mathrm{MiR} 200 \mathrm{c}$ is a crucial modulator of EMT, tumourigenicity, and metastasis $[99,103-105]$. It has been reported that miR200c is down-regulated and exhibits tumour-suppressive properties in renal cell, prostate, breast, bladder, pancreatic, and gastric cancers [106-110]. MiR200c is required for the growth of mammary stem cells and self-renewal properties of breast CSC through the direct targeting of Bmi1 [99]. Down-regulation of miR-200c promotes EMT of breast cancer cells while overexpression of miR-200c induces mesenchymal-epithelial transition $[105,111]$. Notably, miR$200 \mathrm{c}$ was reported to regulate pancreatic cancer cells, EMT, and cancer stemness properties by targeting ZEB1/ZEB2, Bmi-1, and Sox2 [112]. However, the role of miR200c in regulating tumourigenicity and metastasis in HNSCC or HNSCC-CSC has not been reported yet. Our recent study showed that the expression of miR200c in the regional metastatic lymph node of HNSCC tissues was significantly decreased, but Bmi-1 expression was increased as compared to parental tumours (unpublished data). Importantly, the site-directed mutagenesis with luciferase reporter assay showed that miR200c is targeting 3nesis with parental tumours (unpublished data). MiR200cs were significantly down-regulated while Bmi-1 was increased in HNSCC-ALDH $1^{+} / \mathrm{CD} 44^{+}$compared to the other subsets of HNSCC cells. Notably, overexpressing miR200c further down-regulated the protein expressions of ZEB1, snail, and $\mathrm{N}$-cadherin but up-regulated E-cadherin expression in $\mathrm{ALDH}^{+} / \mathrm{CD}_{4} 4^{+}$cells. Xenotransplanted study confirmed that overexpression of miR200c or knockdown of Bmi-1 effectively inhibited the lung metastatic ability and prolonged the survival rate of $\mathrm{ALDH}^{+} / \mathrm{CD} 44^{+}$-transplanted mice. 


\section{Implications of MiRNAs as Biomarkers in HNSCC}

Traditional tumor suppressor or proto-oncogene has been expended to the field of miRNA due to fast progress made in the past decade. Moreover, widespread technology of microarray provides fast and large-scale screening for potential targets in searching appropriate biomarkers. In HNSCC, a number of studies published potential biomarkers for cancer progression as well as prognosis. Even though contradiction among these studies was found, a new era has been opened up for therapeutic strategies in HNSCC. MiR21 is frequently overexpressed in HNSCC. It is the most consistent miRNA found to be upregulated in many studies discussing miRNA profiling in HNSCC $[61,102,113-115]$. Nevertheless, the universal upregulation of miR-21 does not make it an appropriate marker for prognosis. Different conclusions were made in several studies. Cervigne et al. indicated that miR-21 along with miR-181b, and miR-345 are markers for oral cancer progression [116], and Li et al. suggested miR-21 as an indicator for poor prognosis in tongue SCC [51]. No significant result was obtained in other researches [71, 102]. A list of miRNA as potential prognostic marker was provided in Table 4 .

The significance of polymorphisms at miRNA and miRNA target sites in disease risk and prognosis has been addressed and investigated $[117,118]$. Because miRNAs regulate gene expression by binding to $3^{\prime}$ UTR sites, this binding can be affected by single nucleotide polymorphism (SNP) resides within miRNA target sites. MiRNA or miRNA target site polymorphism could abolish the existing target sites or create illegitimate binding sites. These SNPs can therefore affect protein expression and lead to altered organismal phenotypes. According to Saunders et al., a relatively low polymorphism was found in functional region of miRNA while many target sites are disrupted by high frequency of SNPs. In HNSCC, let7-binding site polymorphism at 3'UTR of V-Ki-ras2 Kirsten rat sarcoma viral oncogene homolog (KRAS) (KRAS-LCS6) and sequence polymorphism in miR196A2 are both associated with reduced survival in head and neck cancer $[119,120]$. We recently first demonstrated that let-7a expression was significantly decreased but that Nanog/Oct4 expression was increased in HNSCC tissues as compared to adjacent normal cells (accepted and unpublished data). Expression of let-7a in recurrent HNSCC tissue and in regional metastatic lymph nodes of HNSCC patients was also significantly decreased, but Nanog/Oct4 expression was increased as compared to the expression levels in the parental tumours. Consistently, the stemness genes were significantly up-regulated, and let$7 \mathrm{a}$ was down-regulated in HNSCC-ALDH1 ${ }^{+}$cells relative to HNSCC-ALDH1 ${ }^{-}$cells. Furthermore, lentiviral-mediated let-7a overexpression could significantly inhibit the stemness signature and the chemoresistant abilities of HNSCC$\mathrm{ALDH}^{+}$cells. Most importantly, overexpression of let-7 or knockdown of Nanog in ALDH1 ${ }^{+}$cells effectively blocked tumour metastasis and significantly prolonged survival time in $\mathrm{ALDH} 1^{+}$-transplanted immunocompromised mice. Overall, restoration of let-7a in HNSCC and HNSCC-tumour initiating cells may be a new approach for the therapeutic treatment of HNSCC in the future.

\section{Conclusions}

Traditionally, the major theory of cancer is considered as dysregulation of protein-coding tumor suppressor genes and oncogenes. To date, the discovery of epigenetic regulation provides new explanations to and reveals a more complicated network of cancer formation. MiRNAs, a small group of noncoding RNAs, draw more attention than ever and are thought to be a new category of tumor suppressor or oncogene. Accumulating knowledge in miRNA brings new perspectives in understanding of cell transformation and tumorigenicity. Nevertheless, growing numbers of HNSCC cases need a breakthrough to improve the mortality rate of HNSCC patients. Further studies are needed to understand the mechanism of dysregulation of miRNA as well as their targets.

\section{Conflict of Interests}

The authors declare no conflict of interests.

\section{Authors' Contributions}

L.-H. Chen and K.-L. Tasi contributed equally to this work.

\section{References}

[1] A. Jemal, R. C. Tiwari, T. Murray et al., "Cancer Statistics, 2004," CA: A Cancer Journal for Clinicians, vol. 54, no. 1, pp. 8-29, 2004.

[2] A. Jemal, T. Murray, E. Ward et al., "Cancer statistics, 2005," CA: A Cancer Journal for Clinicians, vol. 55, no. 1, pp. 10-30, 2005.

[3] A. Jemal, R. Siegel, E. Ward et al., "Cancer statistics, 2006," CA: A Cancer Journal for Clinicians, vol. 56, no. 2, pp. 106130, 2006.

[4] A. Jemal, R. Siegel, E. Ward, T. Murray, J. Xu, and M. J. Thun, "Cancer statistics, 2007," CA: A Cancer Journal for Clinicians, vol. 57, no. 1, pp. 43-66, 2007.

[5] A. Jemal, R. Siegel, E. Ward et al., "Cancer statistics, 2008," CA Cancer Journal for Clinicians, vol. 58, no. 2, pp. 71-96, 2008.

[6] A. Jemal, R. Siegel, E. Ward, Y. Hao, J. Xu, and M. J. Thun, "Cancer statistics, 2009," CA Cancer Journal for Clinicians, vol. 59, no. 4, pp. 225-249, 2009.

[7] Y. J. Chen, J. T. C. Chang, C. T. Liao et al., "Head and neck cancer in the betel quid chewing area: recent advances in molecular carcinogenesis," Cancer Science, vol. 99, no. 8, pp. 1507-1514, 2008.

[8] K. A. Gold, H. Y. Lee, and E. S. Kim, "Targeted therapies in squamous cell carcinoma of the head and neck," Cancer, vol. 115, no. 5, pp. 922-935, 2009.

[9] S. Y. Choi and H. Kahyo, "Effect of cigarette smoking and alcohol consumption in the aetiology of cancer of the oral cavity, pharynx and larynx," International Journal of Epidemiology, vol. 20, no. 4, pp. 878-885, 1991.

[10] A. Mashberg, P. Boffetta, R. Winkelman, and L. Garfinkel, "Tobacco smoking, alcohol drinking, and cancer of the oral 
cavity and oropharynx among U.S. Veterans," Cancer, vol. 72, no. 4, pp. 1369-1375, 1993.

[11] G. Menvielle, D. Luce, P. Goldberg, and A. Leclerc, "Smoking, alcohol drinking, occupational exposures and social inequalities in hypopharyngeal and laryngeal cancer," International Journal of Epidemiology, vol. 33, no. 4, pp. 799-806, 2004.

[12] Y. C. Ko, T. A. Chiang, S. J. Chang, and S. F. Hsieh, "Prevalence of betel quid chewing habit in Taiwan and related sociodemographic factors," Journal of Oral Pathology and Medicine, vol. 21, no. 6, pp. 261-264, 1992.

[13] W. L. Lo, S. Y. Kao, L. Y. Chi, Y. K. Wong, and R. C. S. Chang, "Outcomes of oral squamous cell carcinoma in Taiwan after surgical therapy: factors affecting survival," Journal of Oral and Maxillofacial Surgery, vol. 61, no. 7, pp. 751-758, 2003.

[14] K. C. Lai and T. C. Lee, "Genetic damage in cultured human keratinocytes stressed by long-term exposure to areca nut extracts," Mutation Research, vol. 599, no. 1-2, pp. 66-75, 2006.

[15] J. H. Jeng, M. C. Chang, and L. J. Hahn, "Role of areca nut in betel quid-associated chemical carcinogenesis: current awareness and future perspectives," Oral Oncology, vol. 37, no. 6, pp. 477-492, 2001.

[16] L. P. Shirname, M. M. Menon, J. Nair, and S. V. Bhide, "Correlation of mutagenicity and tumorigenicity of betel quid and its ingredients," Nutrition and Cancer, vol. 5, no. 2, pp. 87-91, 1983.

[17] P. H. Lee, M. C. Chang, W. H. Chang et al., "Prolonged exposure to arecoline arrested human $\mathrm{KB}$ epithelial cell growth: regulatory mechanisms of cell cycle and apoptosis," Toxicology, vol. 220, no. 2-3, pp. 81-89, 2006.

[18] A. Argiris, M. V. Karamouzis, D. Raben, and R. L. Ferris, "Head and neck cancer," The Lancet, vol. 371, no. 9625, pp. 1695-1709, 2008.

[19] B. Brockstein, D. J. Haraf, A. W. Rademaker et al., "Patterns of failure, prognostic factors and survival in locoregionally advanced head and neck cancer treated with concomitant chemoradiotherapy: a 9-year, 337-patient, multiinstitutional experience," Annals of Oncology, vol. 15, no. 8, pp. 1179-1186, 2004.

[20] H. M. Chen, M. Y. P. Kuo, K. H. Lin, C. Y. Lin, and C. P. Chiang, "Expression of cyclin A is related to progression of oral squamous cell carcinoma in Taiwan," Oral Oncology, vol. 39, no. 5, pp. 476-482, 2003.

[21] M. Y. P. Kuo, C. Y. Lin, L. J. Hahn, S. J. Cheng, and C. P. Chiang, "Expression of cyclin D1 is correlated with poor prognosis in patients with areca quid chewing-related oral squamous cell carcinomas in Taiwan," Journal of Oral Pathology and Medicine, vol. 28, no. 4, pp. 165-169, 1999.

[22] M. Y. P. Kuo, H. Y. Hsu, S. H. Kok et al., "Prognostic role of p27 expression in oral squamous cell carcinoma in Taiwan," Oral Oncology, vol. 38, no. 2, pp. 172-178, 2002.

[23] J. S. Huang, T. J. Ho, C. P. Chiang, S. H. Kok, Y. S. Kuo, and M. Y. P. Kuo, "MDM2 expression in areca quid chewingassociated oral squamous cell carcinomas in Taiwan," Journal of Oral Pathology and Medicine, vol. 30, no. 1, pp. 53-58, 2001.

[24] S. Y. Liu, C. Y. Yen, S. C. Yang, W. F. Chiang, and K. W. Chang, "Overexpression of Rac-1 small GTPase binding protein in oral squamous cell carcinoma," Journal of Oral and Maxillofacial Surgery, vol. 62, no. 6, pp. 702-707, 2004.

[25] T. J. Ho, C. P. Chiang, C. Y. Hong, S. H. Kok, Y. S. Kuo, and M. Yen-Ping Kuo, "Induction of the c-jun protooncogene expression by areca nut extract and arecoline on oral mucosal fibroblasts," Oral Oncology, vol. 36, no. 5, pp. 432-436, 2000.
[26] W. C. Tsai, S. T. Tsai, J. Y. Ko et al., "The mRNA profile of genes in betel quid chewing oral cancer patients," Oral Oncology, vol. 40, no. 4, pp. 418-426, 2004.

[27] C. Y. Lin, H. C. Hung, R. C. Kuo, C. P. Chiang, and M. Y. P. Kuo, "Survivin expression predicts poorer prognosis in patients with areca quid chewing-related oral squamous cell carcinoma in Taiwan," Oral Oncology, vol. 41, no. 6, pp. 645654, 2005.

[28] I. H. Chen, J. T. Chang, C. T. Liao, H. M. Wang, L. L. Hsieh, and A. J. Cheng, "Prognostic significance of EGFR and Her2 in oral cavity cancer in betel quid prevalent area," British Journal of Cancer, vol. 89, no. 4, pp. 681-686, 2003.

[29] R. Garzon, G. A. Calin, and C. M. Croce, "MicroRNAs in cancer," Annual Review of Medicine, vol. 60, pp. 167-179, 2009.

[30] M. Kato and F. J. Slack, "MicroRNAs: small molecules with big roles-C. elegans to human cancer," Biology of the Cell, vol. 100, no. 2, pp. 71-81, 2008.

[31] M. S. Nicoloso, R. Spizzo, M. Shimizu, S. Rossi, and G. A. Calin, "MicroRNAs - the micro steering wheel of tumour metastases," Nature Reviews Cancer, vol. 9, no. 4, pp. 293302, 2009.

[32] U. A. Ørom, F. C. Nielsen, and A. H. Lund, "MicroRNA-10a binds the 5'UTR of ribosomal protein mRNAs and enhances their translation," Molecular Cell, vol. 30, no. 4, pp. 460-471, 2008.

[33] S. Vasudevan, Y. Tong, and J. A. Steitz, "Switching from repression to activation: microRNAs can up-regulate translation," Science, vol. 318, no. 5858, pp. 1931-1934, 2007.

[34] M. V. Iorio, M. Ferracin, C. G. Liu et al., "MicroRNA gene expression deregulation in human breast cancer," Cancer Research, vol. 65, no. 16, pp. 7065-7070, 2005.

[35] G. A. Calin, C. D. Dumitru, M. Shimizu et al., "Frequent deletions and down-regulation of micro-RNA genes miR15 and miR16 at 13q14 in chronic lymphocytic leukemia," Proceedings of the National Academy of Sciences of the United States of America, vol. 99, no. 24, pp. 15524-15529, 2002.

[36] Y. Xi, R. Shalgi, O. Fodstad, Y. Pilpel, and J. Ju, "Differentially regulated micro-RNAs and actively translated messenger RNA transcripts by tumor suppressor p53 in colon cancer," Clinical Cancer Research, vol. 12, no. 7 I, pp. 2014-2024, 2006.

[37] S. Shin, H. J. Cha, E. M. Lee et al., "MicroRNAs are significantly influenced by p53 and radiation in HCT116 human colon carcinoma cells," International Journal of Oncology, vol. 34, no. 6, pp. 1645-1652, 2009.

[38] L. He, X. He, L. P. Lim et al., "A microRNA component of the p53 tumour suppressor network," Nature, vol. 447, no. 7148, pp. 1130-1134, 2007.

[39] X. Liu, Z. Chen, J. Yu, J. Xia, and X. Zhou, "MicroRNA profiling and head and neck cancer," Comparative and Functional Genomics, vol. 2009, Article ID 837514, 11 pages, 2009.

[40] N. Tran, C. J. O’Brien, J. Clark, and B. Rose, "Potential role of micro-RNAs in head and neck tumorigenesis," Head and Neck, vol. 32, no. 8, pp. 1099-1111, 2010.

[41] L. Hong, Y. Han, H. Zhang et al., "The prognostic and chemotherapeutic value of miR-296 in esophageal squamous cell carcinoma," Annals of Surgery, vol. 251, no. 6, pp. 10561063, 2010.

[42] X. B. Long, G. B. Sun, S. Hu et al., "Let-7a microrna functions as a potential tumor suppressor in human laryngeal cancer," Oncology Reports, vol. 22, no. 5, pp. 1189-1195, 2009. 
[43] X. Liu, L. Jiang, A. Wang, J. Yu, F. Shi, and X. Zhou, "MicroRNA-138 suppresses invasion and promotes apoptosis in head and neck squamous cell carcinoma cell lines," Cancer Letters, vol. 286, no. 2, pp. 217-222, 2009.

[44] L. Jiang, X. Liu, A. Kolokythas et al., "Downregulation of the Rho GTPase signaling pathway is involved in the microRNA138-mediated inhibition of cell migration and invasion in tongue squamous cell carcinoma," International Journal of Cancer, vol. 127, no. 3, pp. 505-512, 2010.

[45] Y. Lee, X. Yang, Y. Huang et al., "Network modeling identifies molecular functions targeted by miR-204 to suppress head and neck tumor metastasis," PLoS Computational Biology, vol. 6, no. 4, article e1000730, 2010.

[46] K. M. Cai, X. L. Bao, X. H. Kong et al., "Hsa-miR$34 \mathrm{c}$ suppresses growth and invasion of human laryngeal carcinoma cells via targeting c-Met," International Journal of Molecular Medicine, vol. 25, no. 4, pp. 565-571, 2010.

[47] L. Zhang, T. Dengy, X. Li et al., "microRNA-141 is involved in a nasopharyngeal carcinoma-related genes network," Carcinogenesis, vol. 31, no. 4, pp. 559-566, 2010.

[48] H. Ke, J. Pei, Z. Ni et al., "Putative tumor suppressor Lats2 induces apoptosis through downregulation of Bcl-2 and Bcl$\mathrm{x}(\mathrm{L})$," Experimental Cell Research, vol. 298, no. 2, pp. 329$338,2004$.

[49] N. Yabuta, N. Okada, A. Ito et al., "Lats2 is an essential mitotic regulator required for the coordination of cell division," Journal of Biological Chemistry, vol. 282, no. 26, pp. 19259-19271, 2007.

[50] K. H. Lee, Y. G. Goan, M. Hsiao et al., "MicroRNA-373 (miR373) post-transcriptionally regulates large tumor suppressor, homolog 2 (LATS2) and stimulates proliferation in human esophageal cancer," Experimental Cell Research, vol. 315, no. 15, pp. 2529-2538, 2009.

[51] J. Li, H. Huang, L. Sun et al., "MiR-21 indicates poor prognosis in tongue squamous cell carcinomas as an apoptosis inhibitor," Clinical Cancer Research, vol. 15, no. 12, pp. 39984008, 2009.

[52] Z. Lu, M. Liu, V. Stribinskis et al., "MicroRNA-21 promotes cell transformation by targeting the programmed cell death 4 gene," Oncogene, vol. 27, no. 31, pp. 4373-4379, 2008.

[53] Y. Hiyoshi, H. Kamohara, R. Karashima et al., "MicroRNA21 regulates the proliferation and invasion in esophageal squamous cell carcinoma," Clinical Cancer Research, vol. 15, no. 6, pp. 1915-1922, 2009.

[54] Y.-W. Chen, K.-H. Chen, P.-I. Huang et al., "Cucurbitacin I suppressed stem-like property and enhanced radiationinduced apoptosis in head and neck squamous carcinomaderived $\mathrm{CD} 44^{+} \mathrm{ALDH}^{+}$cells," Molecular Cancer Therapeutics, vol. 9, no. 11, pp. 2879-2892, 2010.

[55] K. H. Haider, N. M. Idris, H. W. Kim, R. P. H. Ahmed, J. Shujia, and M. Ashraf, "MicroRNA-21 is a key determinant in IL-11/Stat3 anti-apoptotic signalling pathway in preconditioning of skeletal myoblasts," Cardiovascular Research, vol. 88, no. 1, pp. 168-178, 2010.

[56] D. Iliopoulos, S. A. Jaeger, H. A. Hirsch, M. L. Bulyk, and K. Struhl, "STAT3 activation of miR-21 and miR-181b-1 via PTEN and CYLD are part of the epigenetic switch linking inflammation to cancer," Molecular Cell, vol. 39, no. 4, pp. 493-506, 2010.

[57] K. W. Chang, C. J. Liu, T. H. Chu et al., "Association between high miR-211 microRNA expression and the poor prognosis of oral carcinoma," Journal of Dental Research, vol. 87, no. 11, pp. 1063-1068, 2008.
[58] X. Liu, J. Yu, L. Jiang et al., "MicroRNA-222 regulates cell invasion by targeting matrix metalloproteinase 1 (MMP1) and manganese superoxide dismutase 2 (SOD2) in tongue squamous cell carcinoma cell lines," Cancer Genomics and Proteomics, vol. 6, no. 3, pp. 134-139, 2009.

[59] Q. Jiang, M. G. Feng, and Y. Y. Mo, "Systematic validation of predicted microRNAs for cyclin D1," BMC Cancer, vol. 9, article 194, 2009.

[60] E. E. W. Cohen, H. Zhu, M. W. Lingen et al., "A feed-forward loop involving protein kinase $\mathrm{C} \alpha$ and microRNAs regulates tumor cell cycle," Cancer Research, vol. 69, no. 1, pp. 65-74, 2009.

[61] T. S. Wong, X. B. Liu, B. Y. H. Wong, R. W. M. Ng, A. P. W. Yuen, and W. I. Wei, "Mature miR-184 as potential oncogenic microRNA of squamous cell carcinoma of tongue," Clinical Cancer Research, vol. 14, no. 9, pp. 2588-2592, 2008.

[62] B. J. Henson, S. Bhattacharjee, D. M. O’Dee, E. Feingold, and S. M. Gollin, "Decreased expression of miR-125b and miR100 in oral cancer cells contributes to malignancy," Genes Chromosomes and Cancer, vol. 48, no. 7, pp. 569-582, 2009.

[63] F. Wu, S. Zhu, Y. Ding, W. T. Beck, and Y. Y. Mo, "MicroRNAmediated regulation of Ubc9 expression in cancer cells," Clinical Cancer Research, vol. 15, no. 5, pp. 1550-1557, 2009.

[64] A. M. Lena, R. Shalom-Feuerstein, P. R. di Val Cervo et al., “miR-203 represses "stemness" by repressing $\Delta$ Np63," Cell Death and Differentiation, vol. 15, no. 7, pp. 1187-1195, 2008.

[65] P. Silva, N. J. Slevin, P. Sloan et al., "Prognostic significance of tumor hypoxia inducible factor- $1 \alpha$ expression for outcome after radiotherapy in oropharyngeal cancer," International Journal of Radiation Oncology Biology Physics, vol. 72, no. 5, pp. 1551-1559, 2008.

[66] S. C. Winter, K. A. Shah, C. Han et al., "The relation between hypoxia-inducible factor (HIF)- $1 \alpha$ and HIF- $2 \alpha$ expression with anemia and outcome in surgically treated head and neck cancer," Cancer, vol. 107, no. 4, pp. 757-766, 2006.

[67] N. J. P. Beasley, R. Leek, M. Alam et al., "Hypoxia-inducible factors HIF- $1 \alpha$ and HIF- $2 \alpha$ in head and neck cancer: relationship to tumor biology and treatment outcome in surgically resected patients," Cancer Research, vol. 62, no. 9, pp. 2493-2497, 2002.

[68] D. S.-S. Hsu, H.-Y. Lan, C.-H. Huang et al., "Regulation of excision repair cross-complementation group 1 by snail contributes to cisplatin resistance in head and neck cancer," Clinical Cancer Research, vol. 16, no. 18, pp. 4561-4571, 2010.

[69] M. H. Yang and K. J. Wu, "TWIST activation by hypoxia inducible factor-1 (HIF-1): implications in metastasis and development," Cell Cycle, vol. 7, no. 14, pp. 2090-2096, 2008.

[70] X. Huang, L. Ding, K. L. Bennewith et al., "Hypoxiainducible mir-210 regulates normoxic gene expression involved in tumor initiation," Molecular Cell, vol. 35, no. 6, pp. 856-867, 2009.

[71] H. E. Gee, C. Camps, F. M. Buffa et al., "hsa-mir-210 is a marker of tumor hypoxia and a prognostic factor in head and neck cancer," Cancer, vol. 116, no. 9, pp. 2148-2158, 2010.

[72] C. J. Liu, S. Y. Kao, H. F. Tu, M. M. Tsai, K. W. Chang, and S. C. Lin, "Increase of microRNA miR-31 level in plasma could be a potential marker of oral cancer," Oral Diseases, vol. 16, no. 4, pp. 360-364, 2010.

[73] C. J. Liu, M. M. Tsai, P. S. Hung et al., "miR-31 ablates expression of the HIF regulatory factor FIH to activate the HIF pathway in head and neck carcinoma," Cancer Research, vol. 70, no. 4, pp. 1635-1644, 2010.

[74] C. Hebert, K. Norris, M. A. Scheper, N. Nikitakis, and J. J. Sauk, "High mobility group A2 is a target for miRNA-98 in 
head and neck squamous cell carcinoma," Molecular Cancer, vol. 6, article 5, 2007.

[75] J. P. Their, "Epithelial-mesenchymal transitions in tumor progression," Nature Reviews Cancer, vol. 2, no. 6, pp. 442 454, 2002.

[76] D. F. Higgins, K. Kimura, W. M. Bernhardt et al., "Hypoxia promotes fibrogenesis in vivo via HIF-1 stimulation of epithelial-to-mesenchymal transition," Journal of Clinical Investigation, vol. 117, no. 12, pp. 3810-3820, 2007.

[77] E. W. Thompson, D. F. Newgreen, and D. Tarin, "Carcinoma invasion and metastasis: a role for epithelial-mesenchymal transition?" Cancer Research, vol. 65, no. 14, pp. 5991-5995, 2005.

[78] J. P. Thiery and J. P. Sleeman, "Complex networks orchestrate epithelial-mesenchymal transitions," Nature Reviews Molecular Cell Biology, vol. 7, no. 2, pp. 131-142, 2006.

[79] A. Cano, M. A. Pérez-Moreno, I. Rodrigo et al., "The transcription factor Snail controls epithelial-mesenchymal transitions by repressing E-cadherin expression," Nature Cell Biology, vol. 2, no. 2, pp. 76-83, 2000.

[80] K. M. Hajra, D. Y. Chen, and E. R. Fearon, "The SLUG zincfinger protein represses E-cadherin in breast cancer," Cancer Research, vol. 62, no. 6, pp. 1613-1618, 2002.

[81] J. Yang, S. A. Mani, J. L. Donaher et al., "Twist, a master regulator of morphogenesis, plays an essential role in tumor metastasis," Cell, vol. 117, no. 7, pp. 927-939, 2004.

[82] M. L. Grooteclaes and S. M. Frisch, "Evidence for a function of CtBP in epithelial gene regulation and anoikis," Oncogene, vol. 19, no. 33, pp. 3823-3828, 2000.

[83] J. Comijn, G. Berx, P. Vermassen et al., "The two-handed E box binding zinc finger protein SIP1 downregulates Ecadherin and induces invasion," Molecular Cell, vol. 7, no. 6, pp. 1267-1278, 2001.

[84] M. A. Pérez-Moreno, A. Locascio, I. Rodrigo et al., "A new role for E12/E47 in the repression of E-cadherin expression and epithelial-mesenchymal transitions," Journal of Biological Chemistry, vol. 276, no. 29, pp. 27424-27431, 2001.

[85] M. H. Yang, S. Y. Chang, S. H. Chiou et al., "Overexpression of NBS1 induces epithelial-mesenchymal transition and coexpression of NBS1 and Snail predicts metastasis of head and neck cancer," Oncogene, vol. 26, no. 10, pp. 1459-1467, 2007.

[86] C. T. Jordan, M. L. Guzman, and M. Noble, "Cancer stem cells," New England Journal of Medicine, vol. 355, no. 12, pp. 1253-1261, 2006.

[87] M. E. Prince, R. Sivanandan, A. Kaczorowski et al., "Identification of a subpopulation of cells with cancer stem cell properties in head and neck squamous cell carcinoma," Proceedings of the National Academy of Sciences of the United States of America, vol. 104, no. 3, pp. 973-978, 2007.

[88] A. Okamoto, K. Chikamatsu, K. Sakakura, K. Hatsushika, G. Takahashi, and K. Masuyama, "Expansion and characterization of cancer stem-like cells in squamous cell carcinoma of the head and neck," Oral Oncology, vol. 45, no. 7, pp. 633639, 2009.

[89] Y. C. Chen, Y. W. Chen, H. S. Hsu et al., "Aldehyde dehydrogenase 1 is a putative marker for cancer stem cells in head and neck squamous cancer," Biochemical and Biophysical Research Communications, vol. 385, no. 3, pp. 307-313, 2009.

[90] S. H. Chiou, C. C. Yu, C. Y. Huang et al., "Positive correlations of Oct-4 and Nanog in oral cancer stem-like cells and high-grade oral squamous cell carcinoma," Clinical Cancer Research, vol. 14, no. 13, pp. 4085-4095, 2008.
[91] Y. C. Chen, C. J. Chang, H. S. Hsu et al., "Inhibition of tumorigenicity and enhancement of radiochemosensitivity in head and neck squamous cell cancer-derived ALDH1positive cells by knockdown of Bmi-1," Oral Oncology, vol. 46, no. 3, pp. 158-165, 2010.

[92] LI. B. Song, J. Li, W. T. Liao et al., "The polycomb group protein Bmi-1 represses the tumor suppressor PTEN and induces epithelial-mesenchymal transition in human nasopharyngeal epithelial cells," Journal of Clinical Investigation, vol. 119, no. 12, pp. 3626-3636, 2009.

[93] J. Ji, T. Yamashita, A. Budhu et al., "Identification of MicroRNA-181 by genome-wide screening as a critical player in EpCAM-positive hepatic cancer stem cells," Hepatology, vol. 50, no. 2, pp. 472-480, 2009.

[94] Q. Ji, X. Hao, M. Zhang et al., "MicroRNA miR-34 inhibits human pancreatic cancer tumor-initiating cells," PLoS ONE, vol. 4, no. 8, Article ID e6816, 2009.

[95] L. Garzia, I. Andolfo, E. Cusanelli et al., "MicroRNA-199b$5 \mathrm{p}$ impairs cancer stem cells through negative regulation of HES1 in medulloblastoma," PLoS ONE, vol. 4, no. 3, Article ID e4998, 2009.

[96] J. Silber, D. A. Lim, C. Petritsch et al., "miR-124 and miR137 inhibit proliferation of glioblastoma multiforme cells and induce differentiation of brain tumor stem cells," $B M C$ Medicine, vol. 6, article 14, 2008.

[97] F. Guessous, Y. Zhang, A. Kofman et al., "microRNA-34a is tumor suppressive in brain tumors and glioma stem cells," Cell Cycle, vol. 9, no. 6, pp. 1031-1036, 2010.

[98] F. Yu, H. Yao, P. Zhu et al., "let-7 regulates self renewal and tumorigenicity of breast cancer cells," Cell, vol. 131, no. 6, pp. 1109-1123, 2007.

[99] Y. Shimono, M. Zabala, R. W. Cho et al., "Downregulation of miRNA-200c links breast cancer stem cells with normal stem cells," Cell, vol. 138, no. 3, pp. 592-603, 2009.

[100] F. Yu, H. Deng, H. Yao, Q. Liu, F. Su, and E. Song, "Mir30 reduction maintains self-renewal and inhibits apoptosis in breast tumor-initiating cells," Oncogene, vol. 29, pp. 41944204, 2010.

[101] T.-S. Wong, X.-B. Liu, A. C.-W. Ho, A. P.-W. Yuen, R. W.M. Ng, and W. I. Wei, "Identification of pyruvate kinase type M2 as potential oncoprotein in squamous cell carcinoma of tongue through microRNA profiling," International Journal of Cancer, vol. 123, no. 2, pp. 251-257, 2008.

[102] G. Childs, M. Fazzari, G. Kung et al., "Low-level expression of microRNAs let-7d and miR-205 are prognostic markers of head and neck squamous cell carcinoma," American Journal of Pathology, vol. 174, no. 3, pp. 736-745, 2009.

[103] M. Korpal, E. S. Lee, G. Hu, and Y. Kang, "The miR-200 family inhibits epithelial-mesenchymal transition and cancer cell migration by direct targeting of E-cadherin transcriptional repressors ZEB1 and ZEB2," Journal of Biological Chemistry, vol. 283, no. 22, pp. 14910-14914, 2008.

[104] S. Spaderna, T. Brabletz, and O. G. Opitz, "The miR-200 family: central player for gain and loss of the epithelial phenotype," Gastroenterology, vol. 136, no. 5, pp. 1835-1837, 2009.

[105] S. M. Park, A. B. Gaur, E. Lengyel, and M. E. Peter, "The miR200 family determines the epithelial phenotype of cancer cells by targeting the E-cadherin repressors ZEB1 and ZEB2," Genes and Development, vol. 22, no. 7, pp. 894-907, 2008.

[106] C. Nakada, K. Matsuura, Y. Tsukamoto et al., "Genomewide microRNA expression profiling in renal cell carcinoma: significant down-regulation of miR-141 and miR-200c," Journal of Pathology, vol. 216, no. 4, pp. 418-427, 2008. 
[107] D. Kong, Y. Li, Z. Wang et al., "miR-200 regulates PDGF-Dmediated epithelial-mesenchymal transition, adhesion, and invasion of prostate cancer cells," Stem Cells, vol. 27, no. 8, pp. 1712-1721, 2009.

[108] A. Shinozaki, T. Sakatani, T. Ushiku et al., "Downregulation of MicroRNA-200 in EBV-associated gastric carcinoma," Cancer Research, vol. 70, no. 11, pp. 4719-4727, 2010.

[109] E. D. Wiklund, J. B. Bramsen, T. Hulf, L. Dyrskjot, R. Ramanathan, and T. B. Hansen, "Coordinated epigenetic repression of the miR-200 family andmiR-205 in invasive bladder cancer," International Journal of Cancer. In press.

[110] R. Baffa, M. Fassan, S. Volinia et al., "MicroRNA expression profiling of human metastatic cancers identifies cancer gene targets," Journal of Pathology, vol. 219, no. 2, pp. 214-221, 2009.

[111] G. J. Hurteau, J. A. Carlson, S. D. Spivack, and G. J. Brock, "Overexpression of the MicroRNA hsa-miR-200c leads to reduced expression of transcription factor 8 and increased expression of E-cadherin," Cancer Research, vol. 67, no. 17, pp. 7972-7976, 2007.

[112] U. Wellner, J. Schubert, U. C. Burk et al., “The EMT-activator ZEB1 promotes tumorigenicity by repressing stemnessinhibiting microRNAs.," Nature cell biology, vol. 11, no. 12, pp. 1487-1495, 2009.

[113] N. Tran, T. McLean, X. Zhang et al., "MicroRNA expression profiles in head and neck cancer cell lines," Biochemical and Biophysical Research Communications, vol. 358, no. 1, pp. 1217, 2007.

[114] S. S. Chang, W. W. Jiang, I. Smith et al., "MicroRNA alterations in head and neck squamous cell carcinoma," International Journal of Cancer, vol. 123, no. 12, pp. 27912797, 2008.

[115] M. Avissar, B. C. Christensen, K. T. Kelsey, and C. J. Marsit, "MicroRNA expression ratio is predictive of head and neck squamous cell carcinoma," Clinical Cancer Research, vol. 15, no. 8, pp. 2850-2855, 2009.

[116] N. K. Cervigne, P. P. Reis, J. Machado et al., "Identification of a microRNA signature associated with progression of leukoplakia to oral carcinoma," Human Molecular Genetics, vol. 18, no. 24, pp. 4818-4829, 2009.

[117] M. A. Saunders, H. Liang, and W. H. Li, "Human polymorphism at microRNAs and microRNA target sites," Proceedings of the National Academy of Sciences of the United States of America, vol. 104, no. 9, pp. 3300-3305, 2007.

[118] K. Chen, F. Song, G. A. Calin, Q. Wei, X. Hao, and W. Zhang, "Polymorphisms in microRNA targets: a gold mine for molecular epidemiology," Carcinogenesis, vol. 29, no. 7, pp. 1306-1311, 2008.

[119] B. C. Christensen, B. J. Moyer, M. Avissar et al., "A let7 microRNA-binding site polymorphism in the KRAS 3" UTR is associated with reduced survival in oral cancers," Carcinogenesis, vol. 30, no. 6, pp. 1003-1007, 2009.

[120] B. C. Christensen, M. Avissar-Whiting, L. G. Ouellet et al., "Mature microRNA sequence polymorphism in MIR196A2 is associated with risk and prognosis of head and neck cancer," Clinical Cancer Research, vol. 16, no. 14, pp. 37133720, 2010.

[121] R. J. Webster, K. M. Giles, K. J. Price, P. M. Zhang, J. S. Mattick, and P. J. Leedman, "Regulation of epidermal growth factor receptor signaling in human cancer cells by MicroRNA-7," Journal of Biological Chemistry, vol. 284, no. 9, pp. 5731-5741, 2009.
[122] J. A. Chan, A. M. Krichevsky, and K. S. Kosik, "MicroRNA21 is an antiapoptotic factor in human glioblastoma cells," Cancer Research, vol. 65, no. 14, pp. 6029-6033, 2005.

[123] I. A. J. Lorimer, "Regulation of p27 by miRNA 221/222 in glioblastoma," Cell Cycle, vol. 8, no. 17, p. 2685, 2009.

[124] J. Novakova, O. Slaby, R. Vyzula, and J. Michalek, "MicroRNA involvement in glioblastoma pathogenesis," Biochemical and Biophysical Research Communications, vol. 386, no. 1, pp. 1-5, 2009.

[125] B. Kefas, J. Godlewski, L. Comeau et al., "microRNA-7 inhibits the epidermal growth factor receptor and the akt pathway and is down-regulated in glioblastoma," Cancer Research, vol. 68, no. 10, pp. 3566-3572, 2008.

[126] S. Volinia, G. A. Calin, C. G. Liu et al., "A microRNA expression signature of human solid tumors defines cancer gene targets," Proceedings of the National Academy of Sciences of the United States of America, vol. 103, no. 7, pp. 2257-2261, 2006.

[127] J. Takamizawa, H. Konishi, K. Yanagisawa et al., "Reduced expression of the let-7 microRNAs in human lung cancers in association with shortened postoperative survival," Cancer Research, vol. 64, no. 11, pp. 3753-3756, 2004.

[128] N. Bandi, S. Zbinden, M. Gugger et al., "miR-15a and miR16 are implicated in cell cycle regulation in a Rb-dependent manner and are frequently deleted or down-regulated in non-small cell lung cancer," Cancer Research, vol. 69, no. 13, pp. 5553-5559, 2009.

[129] M. Fabbri, R. Garzon, A. Cimmino et al., "MicroRNA29 family reverts aberrant methylation in lung cancer by targeting DNA methyltransferases 3A and 3B," Proceedings of the National Academy of Sciences of the United States of America, vol. 104, no. 40, pp. 15805-15810, 2007.

[130] M. W. Nasser, J. Datta, G. Nuovo et al., "Down-regulation of micro-RNA-1 (miR-1) in lung cancer: suppression of tumorigenic property of lung cancer cells and their sensitization to doxorubicin-induced apoptosis by miR-1," Journal of Biological Chemistry, vol. 283, no. 48, pp. 33394-33405, 2008.

[131] L. X. Yan, X. F. Huang, Q. Shao et al., "MicroRNA miR21 overexpression in human breast cancer is associated with advanced clinical stage, lymph node metastasis and patient poor prognosis," RNA, vol. 14, no. 11, pp. 2348-2360, 2008.

[132] S. Valastyan, F. Reinhardt, N. Benaich et al., "A pleiotropically acting microRNA, miR-31, inhibits breast cancer metastasis," Cell, vol. 137, no. 6, pp. 1032-1046, 2009.

[133] M. V. Iorio, P. Casalini, C. Piovan et al., "MicroRNA-205 regulates HER3 in human breast cancer," Cancer Research, vol. 69, no. 6, pp. 2195-2200, 2009.

[134] Y. Wang, A. T. C. Lee, J. Z. I. Ma et al., "Profiling microRNA expression in hepatocellular carcinoma reveals microRNA224 up-regulation and apoptosis inhibitor-5 as a microRNA224-specific target," Journal of Biological Chemistry, vol. 283, no. 19, pp. 13205-13215, 2008.

[135] X. Zhang, S. Liu, T. Hu, S. Liu, Y. He, and S. Sun, "Up-regulated microRNA-143 transcribed by nuclear factor kappa B enhances hepatocarcinoma metastasis by repressing fibronectin expression," Hepatology, vol. 50, no. 2, pp. 490499, 2009.

[136] J. Datta, H. Kutay, M. W. Nasser et al., "Methylation mediated silencing of microRNA-1 gene and its role in hepatocellular carcinogenesis," Cancer Research, vol. 68, no. 13, pp. 50495058, 2008.

[137] L. Gramantieri, M. Ferracin, F. Fornari et al., "Cyclin G1 is a target of miR-122a, a MicroRNA frequently down-regulated 
in human hepatocellular carcinoma," Cancer Research, vol. 67, no. 13, pp. 6092-6099, 2007.

[138] L. Gramantieri, F. Fornari, E. Callegari et al., "MicroRNA involvement in hepatocellular carcinoma: microRNA review series," Journal of Cellular and Molecular Medicine, vol. 12, no. 6A, pp. 2189-2204, 2008.

[139] H. Su, J. R. Yang, T. Xu et al., "MicroRNA-101, downregulated in hepatocellular carcinoma, promotes apoptosis and suppresses tumorigenicity," Cancer Research, vol. 69, no. 3, pp. 1135-1142, 2009.

[140] E. Connolly, M. Melegari, P. Landgraf et al., "Elevated expression of the miR-17-92 polycistron and miR-21 in hepadnavirus-associated hepatocellular carcinoma contributes to the malignant phenotype," American Journal of Pathology, vol. 173, no. 3, pp. 856-864, 2008.

[141] T. Liu, H. Tang, Y. Lang, M. Liu, and X. Li, "MicroRNA27a functions as an oncogene in gastric adenocarcinoma by targeting prohibitin," Cancer Letters, vol. 273, no. 2, pp. 233$242,2009$.

[142] T. Takagi, A. Iio, Y. Nakagawa, T. Naoe, N. Tanigawa, and Y. Akao, "Decreased expression of microRNA-143 and-145 in human gastric cancers," Oncology, vol. 77, no. 1, pp. 12-21, 2009.

[143] Z. Zhang, Z. Li, C. Gao et al., "miR-21 plays a pivotal role in gastric cancer pathogenesis and progression," Laboratory Investigation, vol. 88, no. 12, pp. 1358-1366, 2008.

[144] Y. Saito, G. Liang, G. Egger et al., "Specific activation of microRNA-127 with downregulation of the proto-oncogene BCL6 by chromatin-modifying drugs in human cancer cells," Cancer Cell, vol. 9, no. 6, pp. 435-443, 2006.

[145] I. A. Asangani, S. A. K. Rasheed, D. A. Nikolova et al., "MicroRNA-21 (miR-21) post-transcriptionally downregulates tumor suppressor Pdcd4 and stimulates invasion, intravasation and metastasis in colorectal cancer," Oncogene, vol. 27, no. 15, pp. 2128-2136, 2008.

[146] W. M. Grady, R. K. Parkin, P. S. Mitchell et al., "Epigenetic silencing of the intronic microRNA hsa-miR-342 and its host gene EVL in colorectal cancer," Oncogene, vol. 27, no. 27, pp. 3880-3888, 2008.

[147] M. Toyota, H. Suzuki, Y. Sasaki et al., "Epigenetic silencing of microRNA-34b/c and B-cell translocation gene 4 is associated with $\mathrm{CpG}$ island methylation in colorectal cancer," Cancer Research, vol. 68, no. 11, pp. 4123-4132, 2008.

[148] H. Tazawa, N. Tsuchiya, M. Izumiya, and H. Nakagama, "Tumor-suppressive miR-34a induces senescencelike growth arrest through modulation of the E2F pathway in human colon cancer cells," Proceedings of the National Academy of Sciences of the United States of America, vol. 104, no. 39, pp. 15472-15477, 2007.

[149] O. Slaby, M. Svoboda, P. Fabian et al., "Altered expression of miR-21, miR-31, miR-143 and miR-145 is related to clinicopathologic features of colorectal cancer," Oncology, vol. 72, no. 5-6, pp. 397-402, 2008.

[150] S. Varambally, Q. Cao, R. S. Mani et al., "Genomic loss of microRNA-101 leads to overexpression of histone methyltransferase EZH2 in cancer," Science, vol. 322, no. 5908, pp. 1695-1699, 2008.

[151] D. Bonci, V. Coppola, M. Musumeci et al., "The miR15a-miR-16-1 cluster controls prostate cancer by targeting multiple oncogenic activities," Nature Medicine, vol. 14, no. 11, pp. 1271-1277, 2008 .
[152] E. J. Noonan, R. F. Place, D. Pookot et al., "MiR-449a targets HDAC-1 and induces growth arrest in prostate cancer," Oncogene, vol. 28, no. 14, pp. 1714-1724, 2009.

[153] S. Galardi, N. Mercatelli, E. Giorda et al., "miR-221 and miR222 expression affects the proliferation potential of human prostate carcinoma cell lines by targeting p27," Journal of Biological Chemistry, vol. 282, no. 32, pp. 23716-23724, 2007.

[154] J. Kluiver, S. Poppema, D. de Jong et al., "BIC and miR-155 are highly expressed in Hodgkin, primary mediastinal and diffuse large B cell lymphomas," Journal of Pathology, vol. 207, no. 2, pp. 243-249, 2005.

[155] L. He, J. M. Thomson, M. T. Hemann et al., "A microRNA polycistron as a potential human oncogene," Nature, vol. 435, no. 7043, pp. 828-833, 2005.

[156] Y. Akao, Y. Nakagawa, Y. Kitade, T. Kinoshita, and T. Naoe, "Downregulation of microRNAs-143 and -145 in B-cell malignancies," Cancer Science, vol. 98, no. 12, pp. 1914-1920, 2007.

[157] B. Stamatopoulos, N. Meuleman, B. Haibe-Kains et al., "microRNA-29c and microRNA-223 down-regulation has in vivo significance in chronic lymphocytic leukemia and improves disease risk stratification," Blood, vol. 113, no. 21, pp. 5237-5245, 2009.

[158] V. Fulci, S. Chiaretti, M. Goldoni et al., "Quantitative technologies establish a novel microRNA profile of chronic lymphocytic leukemia," Blood, vol. 109, no. 11, pp. 49444951, 2007.

[159] M. K. Dijkstra, K. van Lom, D. Tielemans et al., "17p13/TP53 deletion in B-CLL patients is associated with microRNA-34a downregulation," Leukemia, vol. 23, no. 3, pp. 625-627, 2009.

[160] Y. Pekarsky, U. Santanam, A. Cimmino et al., “Tcl1 expression in chronic lymphocytic leukemia is regulated by miR-29 and miR-181," Cancer Research, vol. 66, no. 24, pp. 11590 11593, 2006.

[161] M. Avissar, M. D. McClean, K. T. Kelsey, and C. J. Marsit, "MicroRNA expression in head and neck cancer associates with alcohol consumption and survival," Carcinogenesis, vol. 30, no. 12, pp. 2059-2063, 2009.

[162] H. C. Chen, G. H. Chen, Y. H. Chen et al., "MicroRNA deregulation and pathway alterations in nasopharyngeal carcinoma," British Journal of Cancer, vol. 100, no. 6, pp. 1002-1011, 2009.

[163] J. Jiang, E. J. Lee, Y. Gusev, and T. D. Schmittgen, "Realtime expression profiling of microRNA precursors in human cancer cell lines," Nucleic Acids Research, vol. 33, no. 17, pp. 5394-5403, 2005.

[164] K. I. Kozaki, I. Imoto, S. Mogi, K. Omura, and J. Inazawa, "Exploration of tumor-suppressive microRNAs silenced by DNA hypermethylation in oral cancer," Cancer Research, vol. 68, no. 7, pp. 2094-2105, 2008.

[165] L. Ramdas, U. Giri, C. L. Ashorn et al., "miRNA expression profiles in head and neck squamous cell carcinoma and adjacent normal tissue," Head and Neck, vol. 31, no. 5, pp. 642-654, 2009.

[166] S. Sengupta, J. A. Den Boon, I. H. Chen et al., "MicroRNA $29 \mathrm{c}$ is down-regulated in nasopharyngeal carcinomas, upregulating mRNAs encoding extracellular matrix proteins," Proceedings of the National Academy of Sciences of the United States of America, vol. 105, no. 15, pp. 5874-5878, 2008.

[167] X. Zhang, M. Cairns, B. Rose et al., "Alterations in miRNA processing and expression in pleomorphic adenomas of the 
salivary gland," International Journal of Cancer, vol. 124, no. 12, pp. 2855-2863, 2009.

[168] N. J. Park, H. Zhou, D. Elashoff et al., "Salivary microRNA: discovery, characterization, and clinical utility for oral cancer detection," Clinical Cancer Research, vol. 15, no. 17, pp. 54735477, 2009.

[169] Y. Tian, A. Luo, Y. Cai et al., "MicroRNA-10b promotes migration and invasion through KLF4 in human esophageal cancer cell lines," Journal of Biological Chemistry, vol. 285, no. 11, pp. 7986-7994, 2010. 


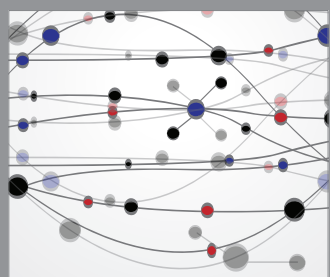

The Scientific World Journal
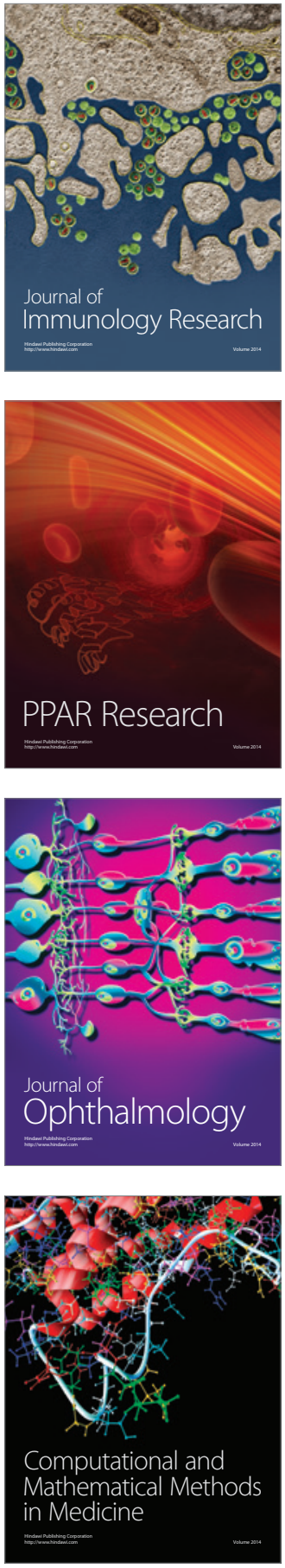

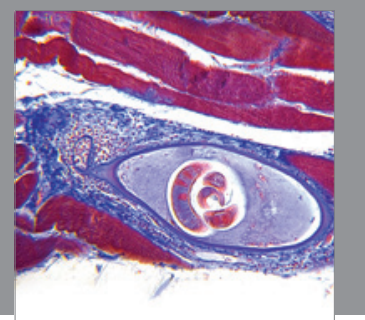

Gastroenterology

Research and Practice
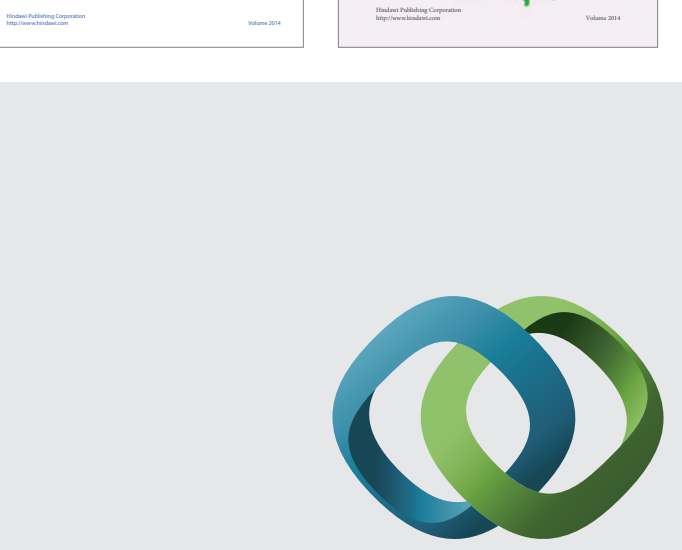

\section{Hindawi}

Submit your manuscripts at

http://www.hindawi.com
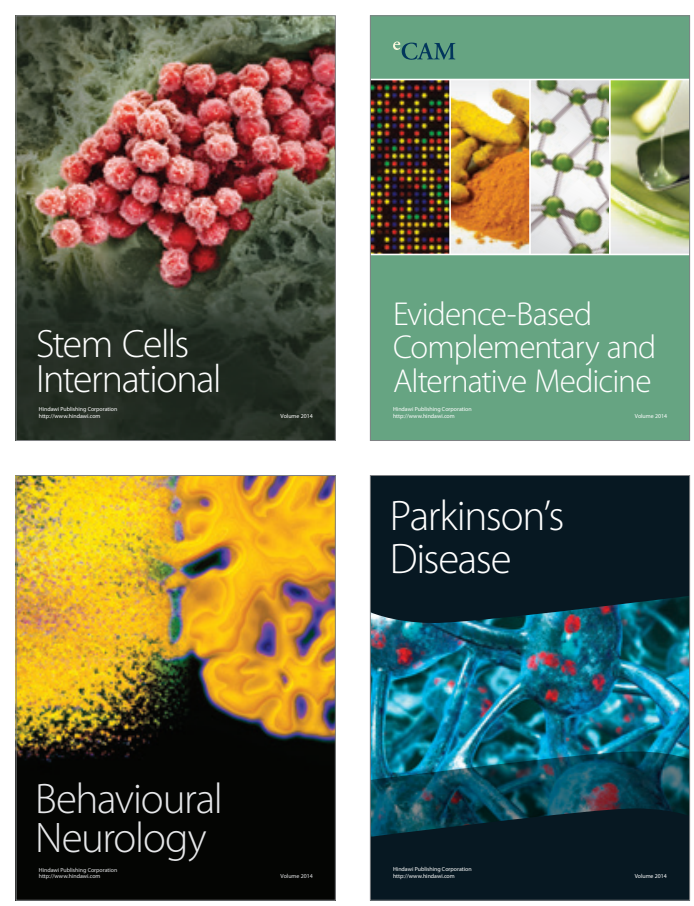

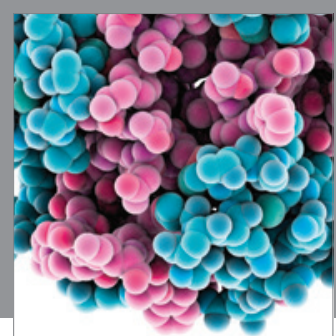

Journal of
Diabetes Research

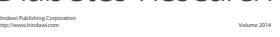

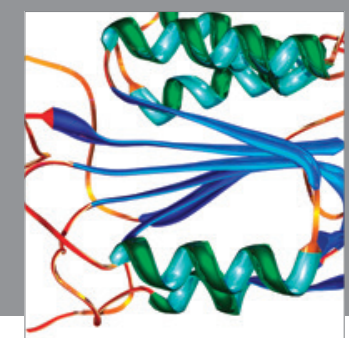

Disease Markers
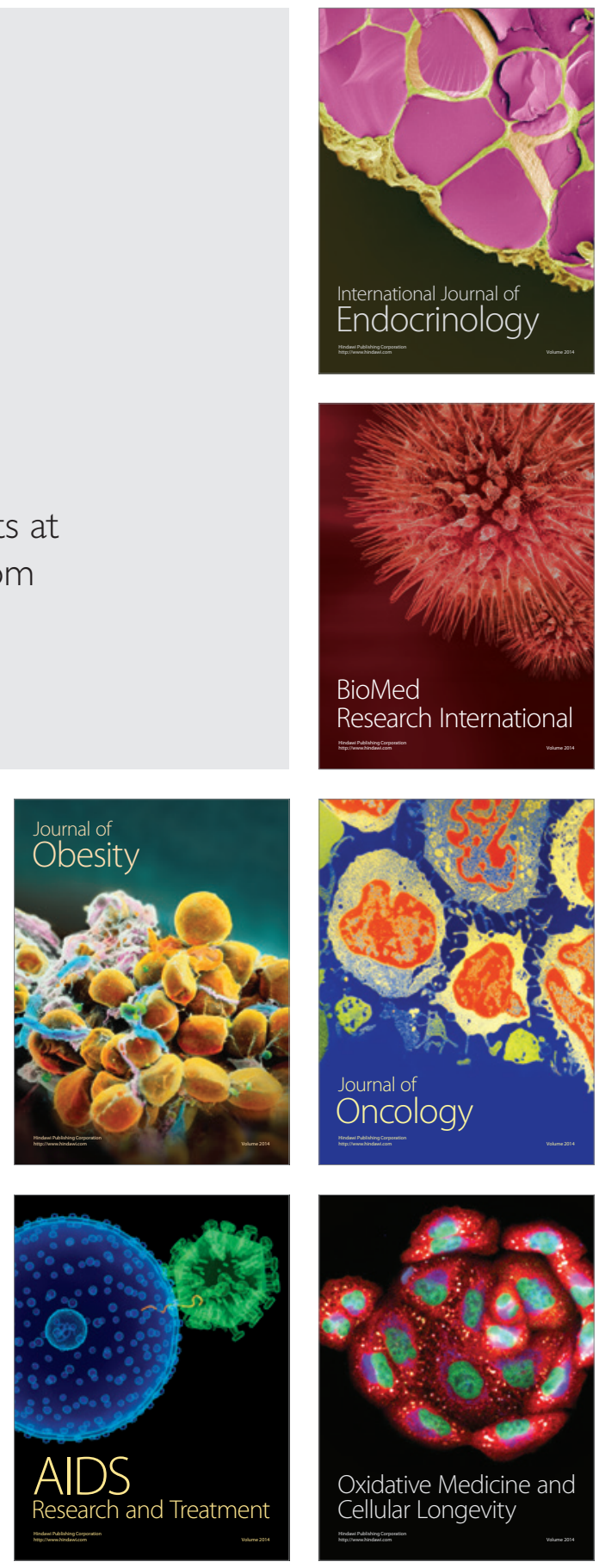